\title{
Molecular phylogenetic analysis of the Paguristes tortugae Schmitt, 1933 complex and selected other Paguroidea (Crustacea: Decapoda: Anomura)
}

\author{
CATHERINE W. CRAIG ${ }^{1 *} \&$ DARRYL L. FELDER ${ }^{1}$ \\ ${ }^{1}$ Department of Biology and Laboratory for Crustacean Research, University of Louisiana at Lafayette, P.O. Box 42451, Lafayette, \\ Louisiana, 70504-2451, USA." darryl.felder1@louisiana.edu; @ https://orcid.org/0000-0001-7679-7712 \\ ${ }^{*}$ Corresponding author. $=\mid$ catherinew.craig08@gmail.com; ○ https://orcid.org/0000-0002-3479-2654
}

\begin{abstract}
Morphological characters, as presently applied to describe members of the Paguristes tortugae Schmitt, 1933 species complex, appear to be of limited value in inferring phylogenetic relationships within the genus, and may have similarly misinformed understanding of relationships between members of this complex and those presently assigned to the related genera Areopaguristes Rahayu \& McLaughlin, 2010 and Pseudopaguristes McLaughlin, 2002. Previously undocumented observations of similarities and differences in color patterns among populations additionally suggest genetic divergences within some species, or alternatively seem to support phylogenetic groupings of some species. In the present study, a Maximum Likelihood (ML) phylogenetic analysis was undertaken based on the H3, 12S mtDNA, and 16S mtDNA sequences of 148 individuals, primarily representatives of paguroid species from the western Atlantic. This molecular analysis supported a polyphyletic Diogenidae Ortmann, 1892, although incomplete taxonomic sampling among the genera of Diogenidae limits the utility of this finding for resolving family level relationships. Several hypotheses regarding the evolutionary relationships among hermit crab genera were refuted by the Kishino-Hasegawa (KH). ShimodairaHasegawa (SH) and Approximately Unbiased (AU) tree topology tests, among them the hypothesis that Areopaguristes is monophyletic. A lack of support for the monophyly of Areopaguristes calls into question the phylogenetic validity of gill number for the differentiation of Paguristes, Areopaguristes, and Pseudopaguristes. The study was inconclusive with regard to the relationships among these three genera, but previously unknown diversity within both Paguristes and Areopaguristes was demonstrated. Existence of an undescribed species confounded under the name Paguristes tortugae Schmitt, 1933 was supported by genetics, morphology, and coloration. A second undescribed species with remarkable similarity to Areopaguristes hummi Wass, 1955 was discovered based on genetics and coloration.
\end{abstract}

Key words: Diogenidae, systematics, hermit crab, mtDNA, 16S, 12S, Histone 3

\section{Introduction}

Within the infraorder Anomura, the superfamily Paguroidea (sensu McLaughlin et al. 2010) includes nearly 1200 species by current estimates (Lemaitre \& McLaughlin 2020; WoRMS 2020). These hermit crabs are nearly ubiquitous in coastal marine environments from the intertidal to abyssal depths. A large body of morphological and genetic research on paguroid systematics has focused on the relationships between controversial, large-scale groupings (family level and above), as well as the phenomenon of carcinization (MacDonald et al. 1957; McLaughlin 1983; Forest 1987; Cunningham et al. 1992; Scholtz \& Richter 1995; Morrison et al. 2002; Dixon et al. 2003; Ahyong et al. 2009; McLaughlin et al. 2007; Reimann et al. 2011; Tsang et al. 2011; Bracken-Grissom et al. 2013; Keiler et al. 2017; Palero et al. 2019). Emerging evidence from molecular phylogenetics, CO1 barcoding studies, and phylogenomic analyses demonstrates that evolutionary relationships within Anomura and among paguroid groups are not always clear cut, suggesting that the taxonomic scope of some families and many of the genera they encompass will require revisions in order to reconcile current classifications with phylogenetic relationships (Landschoff \& Gouws 2018; Noever \& Glenner 2018; Tan et al. 2018; Wolfe et al. 2019).

One of the most species-rich genera of diogenid hermit crabs with diverse morphology and coloration as well as global distribution is Paguristes Dana, 1851. Paguristes is typified by the eastern Pacific species Paguristes hir- 
tus Dana, 1851, a taxon placed into synonymy with P. weddellii H. Milne Edwards, 1848 by Haig (1955), though this synonymy was recently called into question in the reassignment of $P$. weddellii to Tetralobistes Ayon-Parente \& Hendrickx, 2010 (Ayon-Parente \& Hendrickx 2013). Paguristes, as currently considered, is generally diagnosed by the presence of distinctive, paired first and second male pleopods modified as gonopods, 13 pairs of gills, and non-cheliform fourth pereopods (Dana 1851; Forest \& McLaughlin 2000; Schweitzer \& Feldmann 2001; Rahayu 2005).

In our opinion, two additional diogenid genera, Pseudopaguristes McLaughlin, 2002 and Areopaguristes Rahayu \& McLaughlin, 2010, must be considered along with any discussion of Paguristes. Pseudopaguristes was established with P. janetkae McLaughlin, 2002 from Guam as the type species. Paired gonopods were noted to occur in P. janetkae that implied a relationship to Paguristes. However, a lesser number of gill pairs, 8 rather than 13, was considered by McLaughlin (2002) to necessitate the establishment of a separate genus. Even though the original generic diagnosis has been somewhat amended (Asakura 2004; Asakura \& Kosuge 2004), the genus continues to be expanded upon and at present includes around 13 species from the western Pacific and two species from the western Atlantic (Rahayu 2005; Rahayu 2008; McLaughlin et al. 2010; Lemaitre \& McLaughlin 2020; WoRMS 2020). The discovery by Rahayu (2005) of 12 gill pairs in some western Pacific species previously assigned to Paguristes resulted in a reassignment of those taxa to the genus Stratiotes, which was later found to be a preoccupied name and thus replaced by Areopaguristes Rahayu \& McLaughlin, 2010. Membership in Areopaguristes has been expanded since Rahayu's (2005) finding to now include several western Atlantic species with similar characteristics, most of which were also formerly placed in Paguristes. Like Paguristes and Pseudopaguristes, Areopaguristes has so far been presumed monophyletic. Although barcoding efforts have begun to address the issue (Landschoff \& Gouws 2018), neither the monophyly of the three genera nor the association among them have yet been specifically evaluated by a multi-gene molecular phylogenetic analyses.

In the western Atlantic, a prominent subset of the genus Paguristes is comprised of species closely resembling Paguristes tortugae Schmitt, 1933 (McLaughlin \& Provenzano 1974). This informal morphological grouping or complex, includes a number of species that are distributed through the western Atlantic, including within the Gulf of Mexico. The species of this complex, originally defined by McLaughlin \& Provenzano (1974) to include Paguristes tortugae, P. hewatti Wass, 1963, P. angustithecus McLaughlin \& Provenzano, 1974, P. perplexus McLaughlin \& Provenzano, 1974, P. hernancortezi McLaughlin \& Provenzano, 1974, P. anomalus Bouvier, 1918, and P. invisisacculus McLaughlin \& Provenzano, 1974, are characterized primarily by the presence of dense plumose setation on the carapace and thoracic appendages. Since the taxonomic treatment of the complex by McLaughlin \& Provenzano (1974), the proposed constituency of the complex has expanded to now include Paguristes maclaughlinae Martinez-Iglesias \& Gomez, 1989, from Cuba; P. werdingi Campos \& Sanchez, 1995, and P. zebra Campos \& Sanchez, 1995 from Colombia; and P. scarabinoi Lima \& Santana, 2017 from Uruguay. The species of this complex have been regarded as closely related to one another, but no phylogenetic analysis has investigated their relationships on the basis of morphology or genetics. However, $P$. hewatti has been transferred to the genus Areopaguristes on the basis of its 12 gill pairs (Rahayu 2005), and P. invisisacculus was transferred to the genus Pseudopaguristes on the basis of its 8 gill pairs (Rahayu 2005). We question both of these reassignments, especially with their being based solely on gill numbers.

Within the $P$. tortugae complex, some characters are diagnostic at the species level, but there is little consensus as to which morphological features might reliably link species or groups of species within the complex. Many morphological characters that have been applied in comparative studies of the complex are known to vary with specimen size (Provenzano \& Rice 1966; McLaughlin \& Provenzano 1974), while others show high intraspecific variation independent of size (McLaughlin \& Provenzano 1974). Such variability, along with convergent morphological evolution, can obscure true genetic divergence and lead to misinterpretation of evolutionary relationships (Knowlton 1986; Bickford et al. 2007; da Silva et al. 2011). However, modern DNA-based molecular phylogenetic methods provide excellent alternative tools for investigation of cryptic diversity as well as phylogenetic relationships in difficult groups such as the P. tortugae complex (Knowlton 2000; Plaisance et al. 2009; Vrijenhoek 2009; Puillandre et al. 2011; Pante et al. 2015).

Biodiversity studies of decapod crustaceans (Knowlton 1986; Felder et al. 2009b) have increasingly drawn attention to the role of color in detecting cryptic species diversity. Color and its patterning have been shown to support separations at the species level for carideans (Knowlton \& Mills 1992; Grippa \& d'Udekem d'Acoz 1996; Matthews et al. 2002; Rhyne \& Lin 2006; Anker et al. 2008; Bracken \& Felder 2014; Hultgren et al. 2014; Soledade 
et al. 2019), astacideans (Patoka et al. 2015), achelatans (Burton \& Davie 2007; Tourinho et al. 2012), brachyurans (Castro 1982; Williams \& Felder 1986; Ng \& Huang 1997; Davie et al. 2010; Mendoza 2013; Mantelatto et al. 2014; Chenari et al. 2017), and varied anomurans (Macphearson \& Machordom 2001; Hiller et al. 2006; Hiller \& Werding 2019), including paguroid anomurans (Haig \& McLaughlin 1983; Poupin \& McLaughlin 1998; Komai 2001; Malay \& Paulay 2010; Malay et al. 2018; Negri et al. 2012, 2014; Perez-Barros et al. 2015; Jung et al. 2018; Lemaitre et al. 2018; Landschoff \& Gouws 2018; Malay et al. 2018; Felder et al. 2019). In the P. tortugae complex, some constituent species show well-defined and markedly different color schemes with little intraspecific variation or sexual dimorphism (McLaughlin \& Provenzano 1974). Key literature (Provenzano 1959; McLaughlin \& Provenzano 1974; Strasser \& Price 1999), and extensive photographic evidence compiled by us document variation in color among individuals otherwise assignable by current definition as P. tortugae. Although these differences have long been observed, they have historically been regarded as ecomorphic variations of the phenotype closely tied to habitat substrate color (McLaughlin \& Provenzano 1974), which could indeed apply to some paguroid taxa (Mandai et al. 2018).

The present study applies DNA-based molecular phylogenetic methods to illuminate evolutionary relationships among western Atlantic diogenid hermit crabs presently assignable to the $P$. tortugae complex, including suspected constituents of the complex that might have instead been assigned to the genera Areopaguristes and Pseudopaguristes. On the basis of these analyses, this study also explores the utility of color patterns in defining previously known or undescribed cryptic species, as well as the potential use of color in characterization of generic-level clades within the genera Paguristes, Areopaguristes, and Pseudopaguristes.

\section{Materials and methods}

Taxon sampling was biased to western Atlantic representatives of the genus Paguristes with a specific focus on specimens assignable to the P. tortugae complex. Species identifications for specimens included in the analysis were determined from literature accounts related to the complex reports of the Gulf of Mexico fauna (Provenzano 1959, 1965; Felder 1973; McLaughlin \& Provenzano 1974; Abele \& Kim 1986; Strasser \& Price 1999; Felder et al. 2009a). A color photograph database assembled by one of us (DLF) was consulted to identify color variants, and ethanol-preserved voucher specimens for these photographs were integrated into the analyses as possible. Many specimens were accessed from the University of Louisiana Lafayette Zoological Collection (ULLZ), now deposited in the National Museum of Natural History, Smithsonian Institution, Washington DC (USNM), where they remain cross-listed under ULLZ catalog numbers. Other materials for DNA sequencing were accessed from the Florida Museum of Natural History, University of Florida, Gainesville, FL (UF). Specimens selected for DNA sequencing were limited primarily to sequence-quality material collected after 1999. Occasional attempts to sequence older material were also made with varied success. Every effort was made to include at least two representatives of each putative taxon or variant population. Specimens used in this study were either directly preserved in $80 \%$ ethyl alcohol $(\mathrm{EtOH})$ or first frozen in either seawater or glycerol at $-80^{\circ} \mathrm{C}$ before being transferred to $80 \% \mathrm{EtOH}$.

One-hundred-forty-eight individuals representing approximately 60 nominal species of 35 decapod genera were included in the phylogenetic analysis. Histone 3,12S, and $16 \mathrm{~S}$ sequences for 102 individuals were generated for this project, while sequences for the remaining 46 were obtained from GenBank (Table 1). Many high-level anomuran and paguroid relationships are unclear (Ahyong \& O’Meally 2004; Ahyong et al. 2010; Bracken-Grissom et al. 2013; Wolfe et al. 2019), but a general consensus that Brachyura is the sister-group (Forest 1987; Scholtz \& Richter 1995; Dixon 2003; Ahyong \& O'Meally 2004; McLaughlin et al. 2007; De Grave et al. 2009; Bracken-Grissom et al. 2013) continues to be supported by emerging literature (Tan et al. 2015, 2018; Wolfe et al. 2019). Therefore, in addition to eight anomuran species from outside of Paguroidea and four brachyuran representatives were included in the analysis as outgroups.

Genomic DNA was extracted from gill, abdominal tissue, eggs (when available), or whole appendages when necessary, using the Qiagen DNeasy DNA extraction kit (Qiagen, Cat. No. 69504). The DNA purity and concentration was evaluated using the NanoDrop Lite Spectrophotometer (ThermoFisher Scientific, Cat. No. ND-LITE-PR). Two mitochondrial markers and one nuclear marker were selectively amplified using polymerase chain reaction (PCR). A fragment of the mitochondrial large subunit rDNA (16s) of approximately 550 base-pairs (bp) in length was amplified using the primers 16S 1472 and a combination of 16SL2 and 16sar, or primer pair 16s-CWC-01f and 


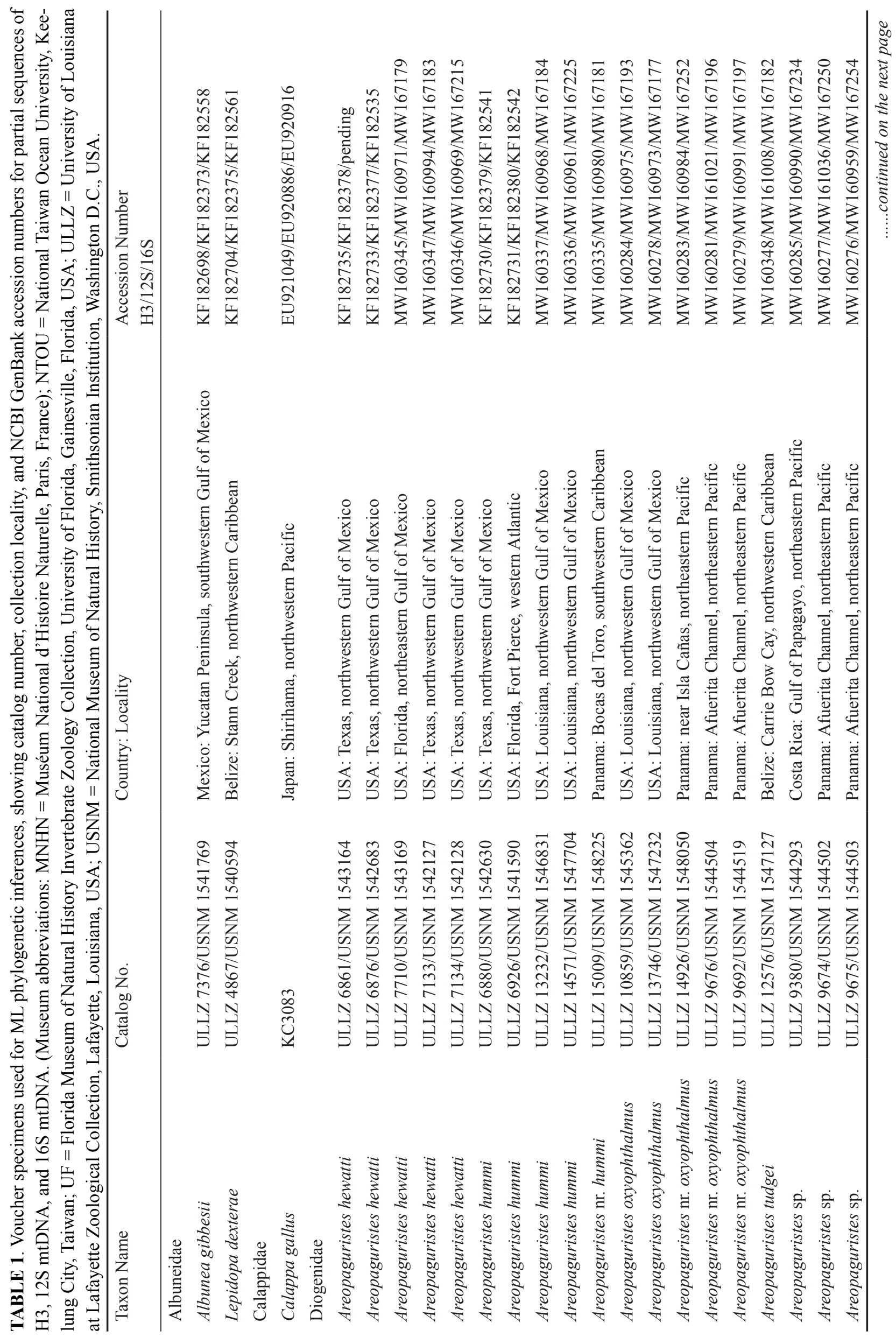




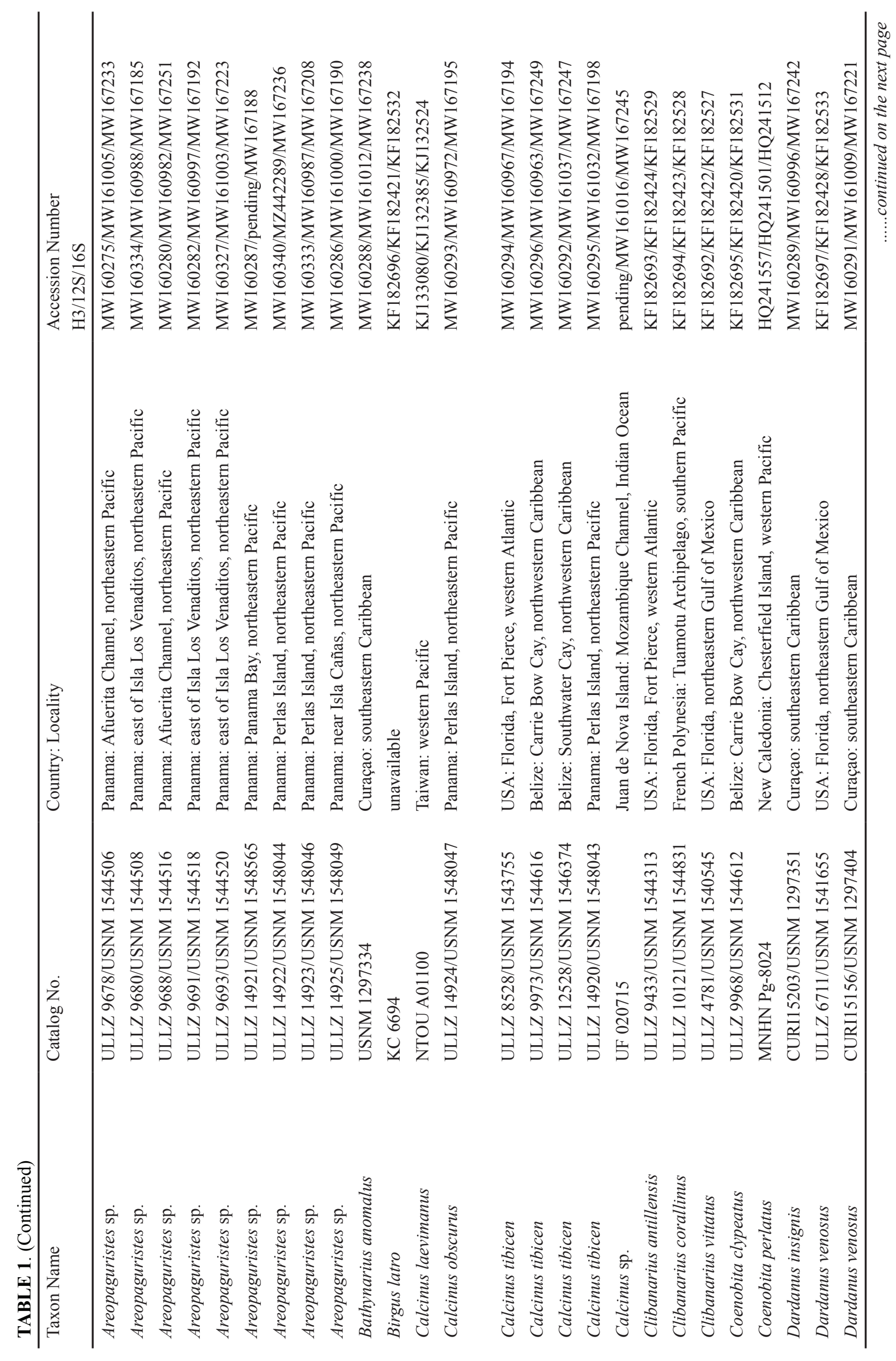




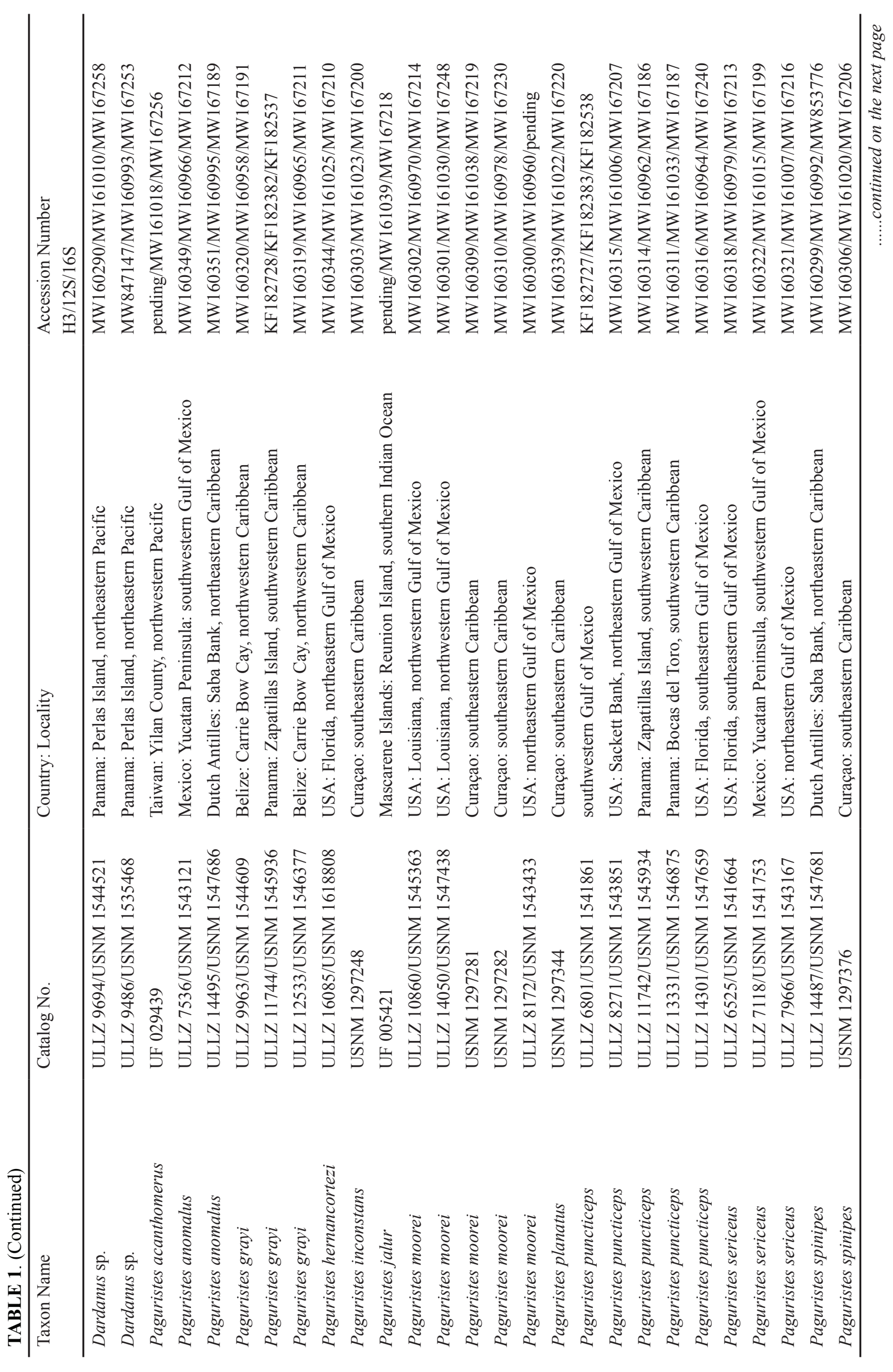




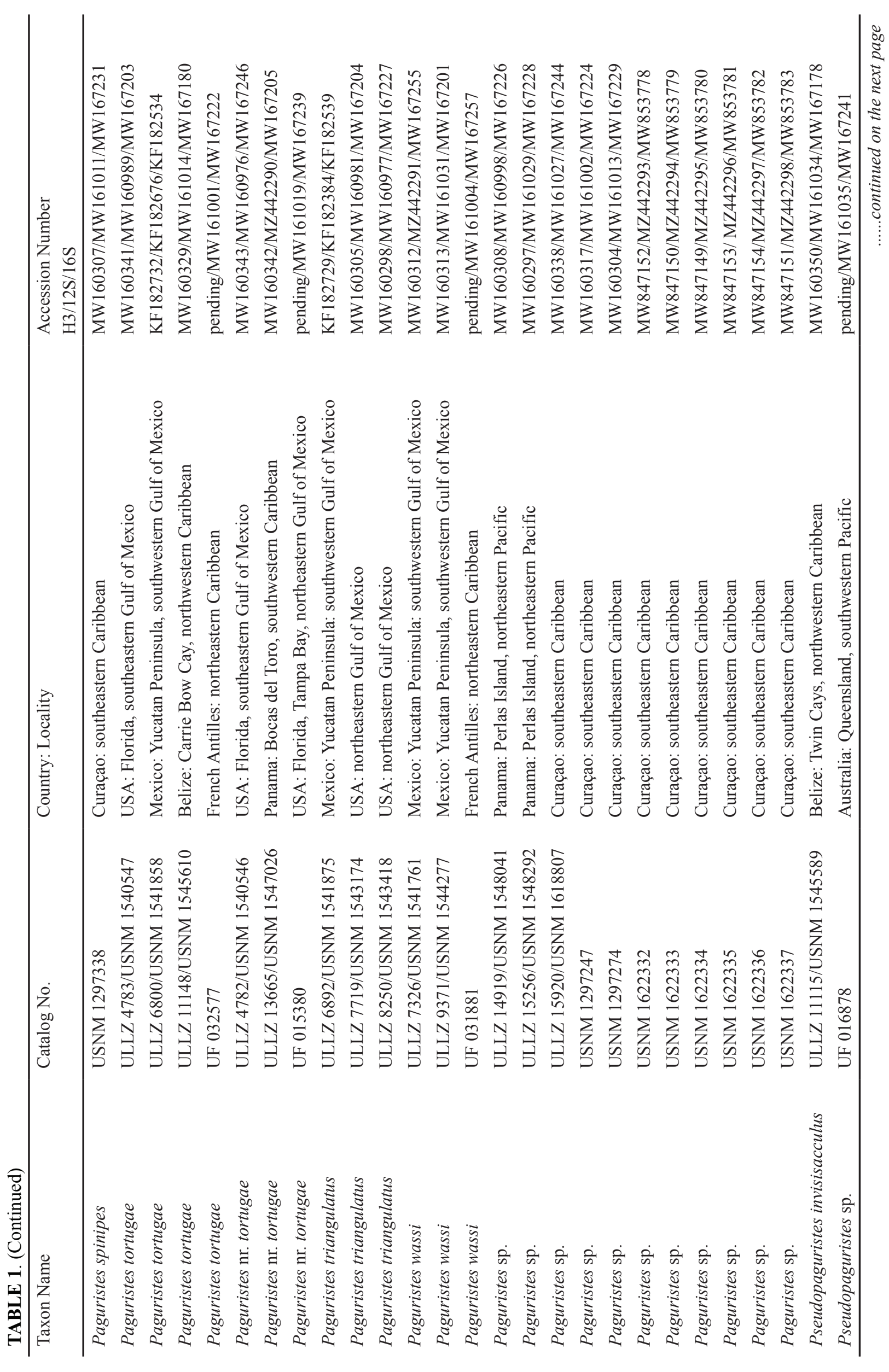

MOLECULAR PHYLOGENETICS OF PAGURISTES TORTUGAE COMPLEX

Zootaxa 4999 (4) (C) 2021 Magnolia Press · 307 


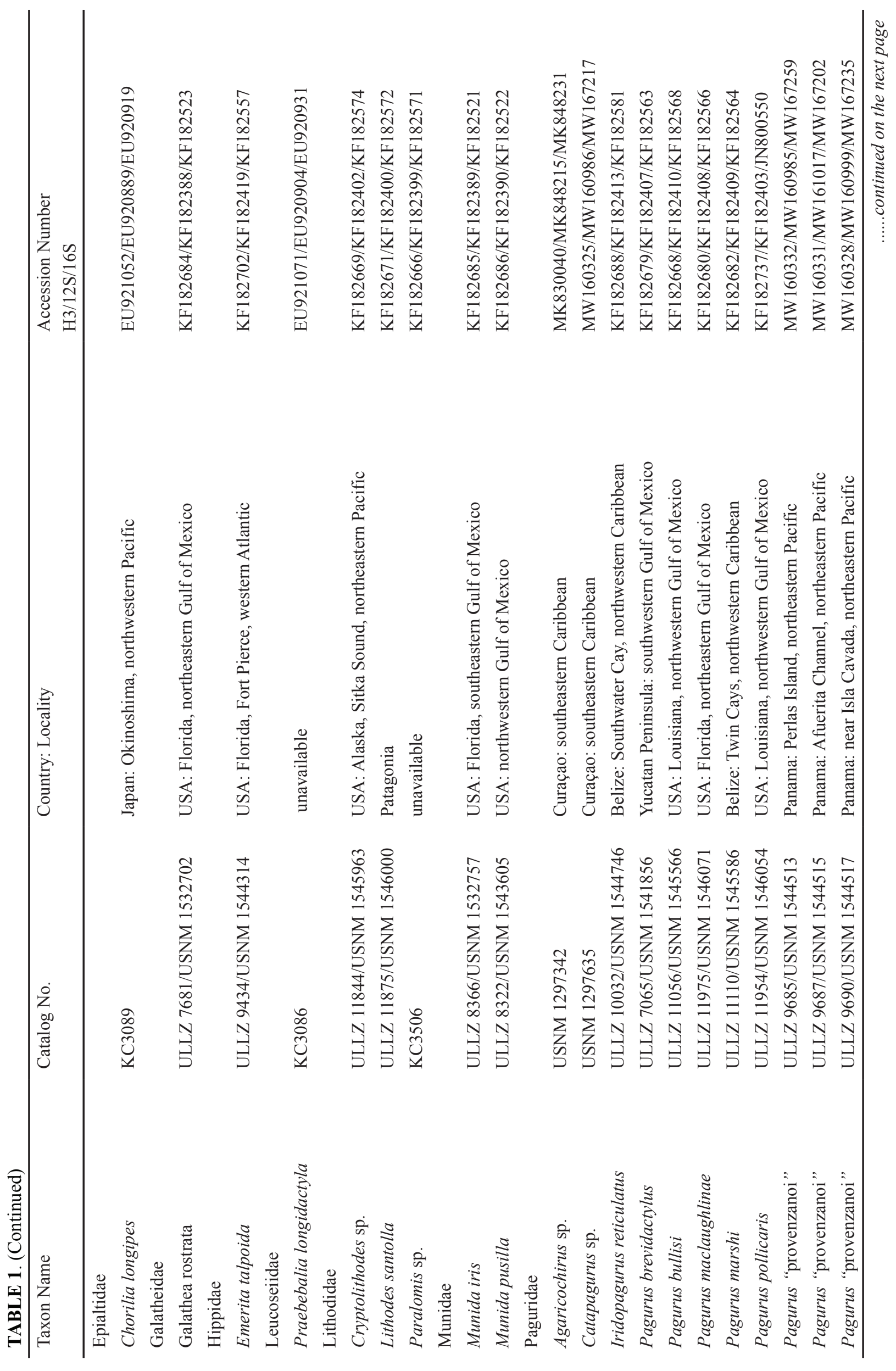




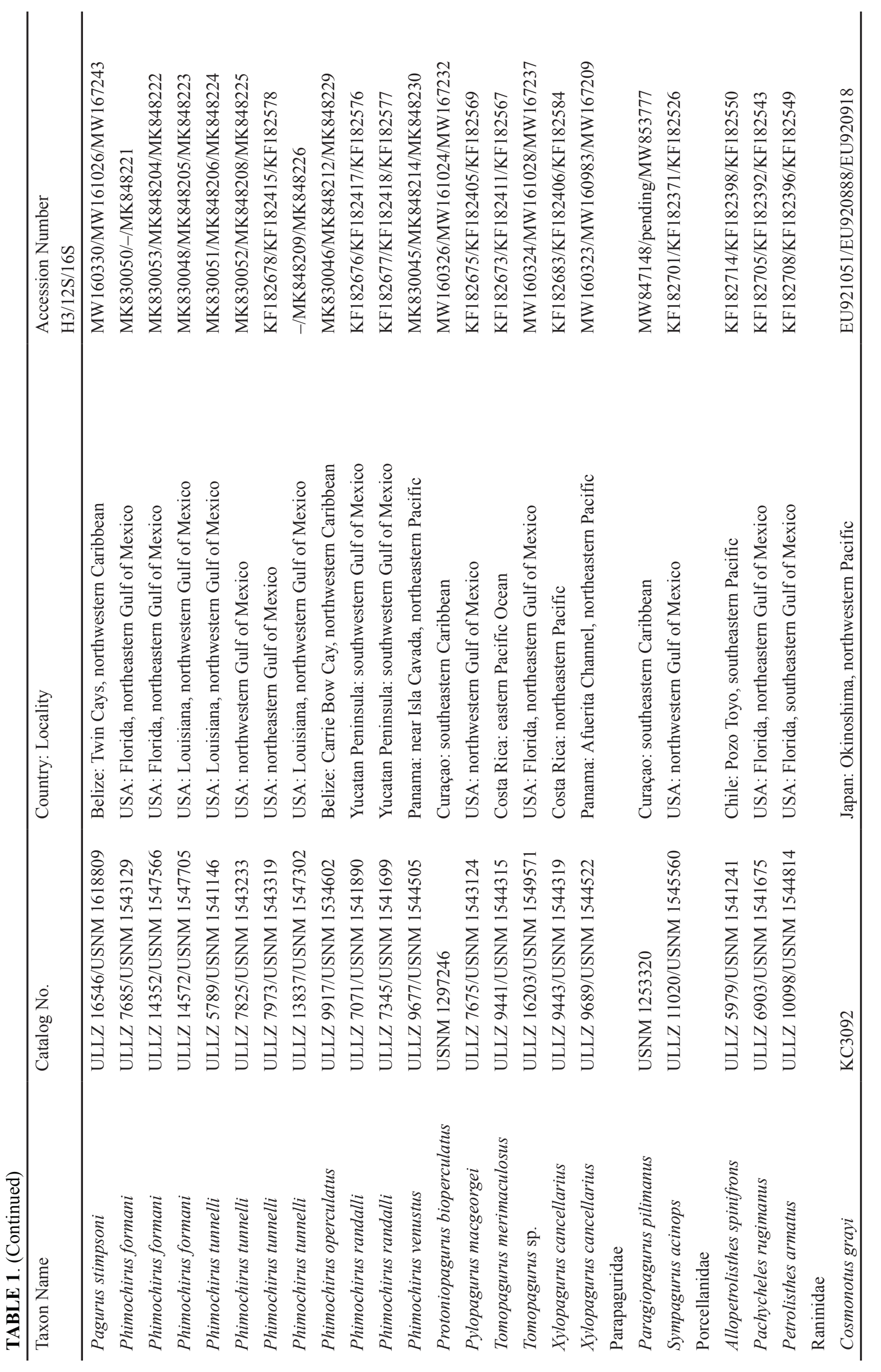


16s-CWC-01r. A fragment of the mitochondrial small subunit rDNA (12S) approximately $310 \mathrm{bp}$ in length was amplified using primers $12 \mathrm{Sf}$ and $12 \mathrm{~S} 1 \mathrm{r}$. A fragment of the nuclear marker, Histone $3(\mathrm{H} 3)$ of approximately $350 \mathrm{bp}$ in length was amplified using primer pair $\mathrm{H} 3 \mathrm{f}$ and $\mathrm{H} 3 \mathrm{r}$. Full primer information is presented in Table 2. Reactions were performed in $25 \mu \mathrm{L}$ volumes using one of four basic mixtures: 1) 30-50 ng DNA template, $0.8 \mu \mathrm{M}$ each primer, 200 $\mu \mathrm{M}$ dNTPs, $2.5 \mu \mathrm{L}$ DreamTaq Green Buffer, 1.5 units DreamTaq Green (ThermoFischer Scientific Inc., Cat. No. EP0712); 2) 30-50 ng DNA template, $0.5 \mu \mathrm{M}$ each primer, $200 \mu \mathrm{M}$ dNTPs, $2.5 \mu \mathrm{L}$ DreamTaq Green Buffer, 1 unit DreamTaq Green; 3) 30-50 ng DNA template, $0.8 \mu \mathrm{M}$ each primer, $200 \mu \mathrm{M}$ dNTPs, $2.5 \mu \mathrm{L}$ DreamTaq Green Buffer, 1.5 units DreamTaq Green, $1 \mu \mathrm{L}$ 1\% Bovine Serum Albumin; 4) 30-50 ng DNA template, $0.4 \mu \mathrm{M}$ each primer, $200 \mu \mathrm{M}$ dNTPs, $2.5 \mu \mathrm{L}$ DreamTaq Green Buffer, 1 unit DreamTaq Green, $1 \mu \mathrm{L}$ 1\% BSA. PCR cycling protocols were as follows: initial denaturation for $3 \mathrm{~min}$ at $96^{\circ} \mathrm{C} ; 35-40$ cycles with denaturation for $30 \mathrm{~s}$ at $96^{\circ} \mathrm{C}$, annealing for $30 \mathrm{~s}$ to $1 \mathrm{~min}$ at $50-54^{\circ} \mathrm{C}(\mathrm{H3af} / \mathrm{H} 3 \mathrm{r}, 12 \mathrm{Sf} / 12 \mathrm{Sr}, 16 \mathrm{~S} 1472 / 16 \mathrm{SL} 2 / 16 \mathrm{Sar})$ or for $45 \mathrm{~s}$ at $56^{\circ} \mathrm{C}(16 \mathrm{~S}-\mathrm{CWC}-01 \mathrm{f} / 16 \mathrm{~S}-$ CWC-01r), elongation for $1 \mathrm{~min}$ at $72^{\circ} \mathrm{C}$; final extension of $10 \mathrm{~min}$ at $72^{\circ} \mathrm{C}$ (Table 2).

TABLE 2. Histone 3 (H3), $12 \mathrm{~S}$ mtDNA, and $16 \mathrm{~S}$ mtDNA primers used in this study.

\begin{tabular}{|c|c|c|c|c|}
\hline Gene & Primer & Primer Sequence & $\begin{array}{l}\text { Annealing } \\
\text { Temperatures }\end{array}$ & Reference \\
\hline H3 forward & H3af & 5' - ATGGCTCTGACCAAGCAGACVGC - 3' & & Colgan et al. 1998 \\
\hline $\mathrm{H} 3$ reverse & $\mathrm{H} 3 \mathrm{r}$ & 5' - ATATCCTTRGGCATRGTGAC - 3' & $\begin{array}{l}50-54^{\circ} \mathrm{C} \text { for } \\
30-60 \mathrm{~s}\end{array}$ & Colgan et al. 1998 \\
\hline $12 \mathrm{~S}$ forward & $12 \mathrm{Sf}$ & 5' - GAAACCAGGATTAGATACCC - 3' & & Buhay et al. 2007 \\
\hline $12 \mathrm{~S}$ reverse & $12 \mathrm{~S} 1 \mathrm{r}$ & 5' - AGCGACGGGCGATATGTATAG - 3' & $\begin{array}{l}50-54^{\circ} \mathrm{C} \text { for } \\
30-60 \mathrm{~s}\end{array}$ & Buhay et al. 2007 \\
\hline $16 \mathrm{~S}$ forward & 16S 1472 & 5' - AGATAGAAACCAACCTGG - 3' & & $\begin{array}{l}\text { Crandall \& Fitz- } \\
\text { patrick } 1996\end{array}$ \\
\hline $16 \mathrm{~S}$ reverse & 16SL2 & 5' - TGCCTGTTTATCAAAAACAT - 3' & & $\begin{array}{l}\text { Schubart et al. } \\
2002\end{array}$ \\
\hline $16 \mathrm{~S}$ reverse & 16Sar & 5' - CGCCTGTTTATCAAAAACAT - 3' & $\begin{array}{l}50-54^{\circ} \mathrm{C} \text { for } \\
30-60 \mathrm{~s}\end{array}$ & Palumbi et al. 1991 \\
\hline $16 \mathrm{~S}$ reverse & 16S-CWC-01r & 5' - CCGGTTTGAACTCAAATCATGT - 3' & & new \\
\hline $16 \mathrm{~S}$ forward & 16S-CWC-01f & 5' - TAAAGTCTAGCCTGCCCACT - 3' & $\begin{array}{l}52-58^{\circ} \mathrm{C} \text { for } \\
30-60 \mathrm{~s}\end{array}$ & new \\
\hline
\end{tabular}

PCR products were purified using SureClean Plus (Bioline USA Inc, SKU 37047). Purified PCR product was cycle-sequenced using the ABI Big-Dye Terminator v3.1 Cycle Sequencing Kit (Applied Biosystems Inc, Foster City, CA, USA). For some sequencing reactions, the manufacturer's protocol for Big-Dye mediated sequencing was modified to accommodate the use of BDX64 Big-Dye Enhancing Buffer (Molecular Cloning Labs, Cat. No. BDX-100), an additive enabling cycle-sequencing with reduced quantities of Big-Dye chain terminators. Cycle sequencing products were purified by filtration though Sephadex G-50 Medium (GE Healthcare Bio-Sciences, Cat. No. 17-0043-01) in Applied Biosystems Centri-Sep Spin Columns (ThermoFisher Scientific, Cat. No. 401762). The samples were then analyzed on an ABI PRISM 3130 Genetic Analyzer (Applied Biosystems Inc., Foster City, CA USA). Sequence contigs were assembled in Sequencher 4.1.2 (GeneCodes Corporation, Ann Arbor, MI). A Multiple Sequence Alignment was generated for each marker individually in MAFFT (Katoh et al. 2002) under G-INS-i criteria for H3, and E-INS-i criteria for $12 \mathrm{~S}$ and 16S (Katoh et al. 2017). Ambiguously aligned regions were trimmed from each alignment by GBlocks (Castresana 2000). Default parameters were used in GBlocks for the H3 marker, but for the 12S and $16 \mathrm{~S}$ alignments the following parameter modifications were made: 1) minimum length of block $=8 ; 2$ ) allowed gap positions $=$ half. The resulting single-gene alignments were concatenated into a single aligned matrix in SequenceMatrix (Vaidya et al. 2011). Model partitions were assigned to alignment regions corresponding to the three individual markers, with the H3 marker further partitioned by codon. A Maximum Likelihood (ML) phylogeny, along with 1000 bootstrap replicates, was inferred in RAxML (Stamatakis 2006) under a GTR+Gamma model of nucleotide substitution. (Rodriguez et al. 1990).

To enable hypothesis testing, an ultrametric constraint tree was generated in Mesquite (Maddison \& Maddison 
2017) by manual restructuring of a generic star phylogeny to reflect a monophyletic Areopaguristes without restricting the placement of Areopaguristes within the overall tree topology. The best ML tree reflecting the constrained topology was inferred using the RAxML (Stamatakis 2006) Black-Box tool available on the CIPRES Science Gateway (Miller et al. 2010) under GTR+Gamma. Additional trees were similarly generated to reflect alternative hypotheses about the relationships among Paguristes, Areopaguristes, and the three subclades of Diogenidae. These included: Paguristes and Areopaguristes as monophyletic sister clades; Diogenidae Clades 1, 2, and 3 united as a single monophyletic clade; Diogenidae Clade $2+$ Coenobitidae + Diogenidae Clade 3 monophyletic and sister to Paguridae Clade $1+$ Lithodidae + Paguridae Clade 2; Diogenidae Clade $2+$ Coenoibitidae + Diogenidae Clade 3 monophyletic and sister to Diogenidae Clade 1 (Table 3). Topology testing in the form of the Approximately Unbiased (AU, Shimodaira 2002), Kishino-Hasegawa (KH, Kishino \& Hasegawa 1989), and Shimodaira-Hasegawa (Shimodaira \& Hasegawa 1999) tests of tree topology was performed in IQtree v1.6.3 (Nguyen et al. 2015; Chernomor et al. 2016). Under all three criteria, topologies with $p$-values less than 0.05 were considered refuted hypotheses that were unlikely to represent an accurate phylogenetic reconstruction (Shimodaira 1999, 2002).

TABLE 3. Results of KH, SH and AU testing in IQtree v1.6.3. Trees are ranked by AU $p$-values. Under the KH, SH and AU metrics, trees with $p$-values $<0.05$ can be excluded from the $95 \%$ confidence set of tree topologies.

\begin{tabular}{lllll}
\hline Constraint & $-\ln L$ & KH & SH & AU \\
\hline Unconstrained ML tree & 30826.652 & & & \\
$\begin{array}{l}\text { Diogenidae Clade 2 + Diogenidae Clade 3 + Coenobitidae sister } \\
\text { to Paguridae + Lithodidae }\end{array}$ & 31034.330 & 0 & $1.8 \mathrm{e}^{-03}$ & $5.60 \mathrm{e}^{-04}$ \\
$\begin{array}{l}\text { Diogenidae Clade 2 + Diogenidae Clade 3 + Coenobitidae sister } \\
\text { to Diogenidae Clade 1 }\end{array}$ & 31271.991 & 0 & 0 & $6.96 \mathrm{e}^{-06}$ \\
Monophyletic Diogenidae & 31005.604 & 0 & $1.33 \mathrm{e}^{-02}$ & $2.02 \mathrm{e}^{-09}$ \\
Monophyletic Areopaguristes & 31238.640 & 0 & 0 & $5.12 \mathrm{e}^{-44}$ \\
Areopaguristes and Paguristes as monophyletic sister clades & 31666.816 & 0 & 0 & $2.15 \mathrm{e}^{-47}$ \\
\hline
\end{tabular}

\section{Results}

The unrefined alignments for the H3, 12S, and $16 \mathrm{~S}$ each incorporated 450, 981, and 821 positions respectively. Removal of ambiguously aligned regions and large gaps resulted in single marker alignments of approximately 214, 329 , and 442 positions. After concatenation, the final alignment length was 987 base pairs for 148 individuals. One thousand nonparametric bootstrap replicates were generated in the course of our phylogenetic analysis and were interpreted as measures of confidence for clades inferred in our most likely ML tree topology (Felsenstein 1985). Bootstrap values are not universally regarded as a reliable measures of clade support (Sanderson 1995; Alfaro et al . 2003; Anisimova \& Gascuel 2006; Susko 2010), but theory and empirical evidence supports their utility in establishing confidence intervals for ML tree topologies generated using data sets similar to ours (Hedges 1992; Hillis \& Bull 1993; Efron et al. 1996; Sanderson 1995; Mort et al. 2000; Soltis \& Soltis 2003; Galtier 2004; Regier et al. 2013; Lemoine et al. 2018). Nodal bootstrap support values of 50 or greater were considered to represent progressively higher levels of quantitative support for the inferred tree topology. Such nodes were consequently treated in subsequent interpretations of our results as credible accounts of the phylogenetic relationships among the species or groups of species united at that node.

The multigene ML analysis revealed deep divisions within the family Diogenidae, which was partitioned into three distinct clades in the best ML tree topology (Fig. 1). Diogenidae Clade 1 (bootstrap 96), was composed of the three genera Paguristes, Areopaguristes, and Pseudopaguristes, all of which were confined to Clade 1. Subdivisions of Diogenidae Clade 1 included four monophyletic subclades as follow: 1) Paguristes tortugae, $P$. nr. tortugae, A. hewatti, P. hernancortezi, P. anomalus, Pseudopaguristes invisisacculus, A. tudgei, and individuals of yet unknown identity (Subclade 1a, bootstrap <50); 2) Paguristes triangulatus, P. grayi, P. spinipes, P. moorei, P. puncticeps, and some species of unknown identities (Subclade 1b, bootstrap <50); 3) Areopaguristes oxyophthalmus, A. nr. oxyophthalmus, and numerous morphologically similar individuals of unknown identity from the eastern Pacific (Subclade 1c, bootstrap 98), 4) Areopaguristes hummi, A. nr. hummi, and morphologically similar individuals of 


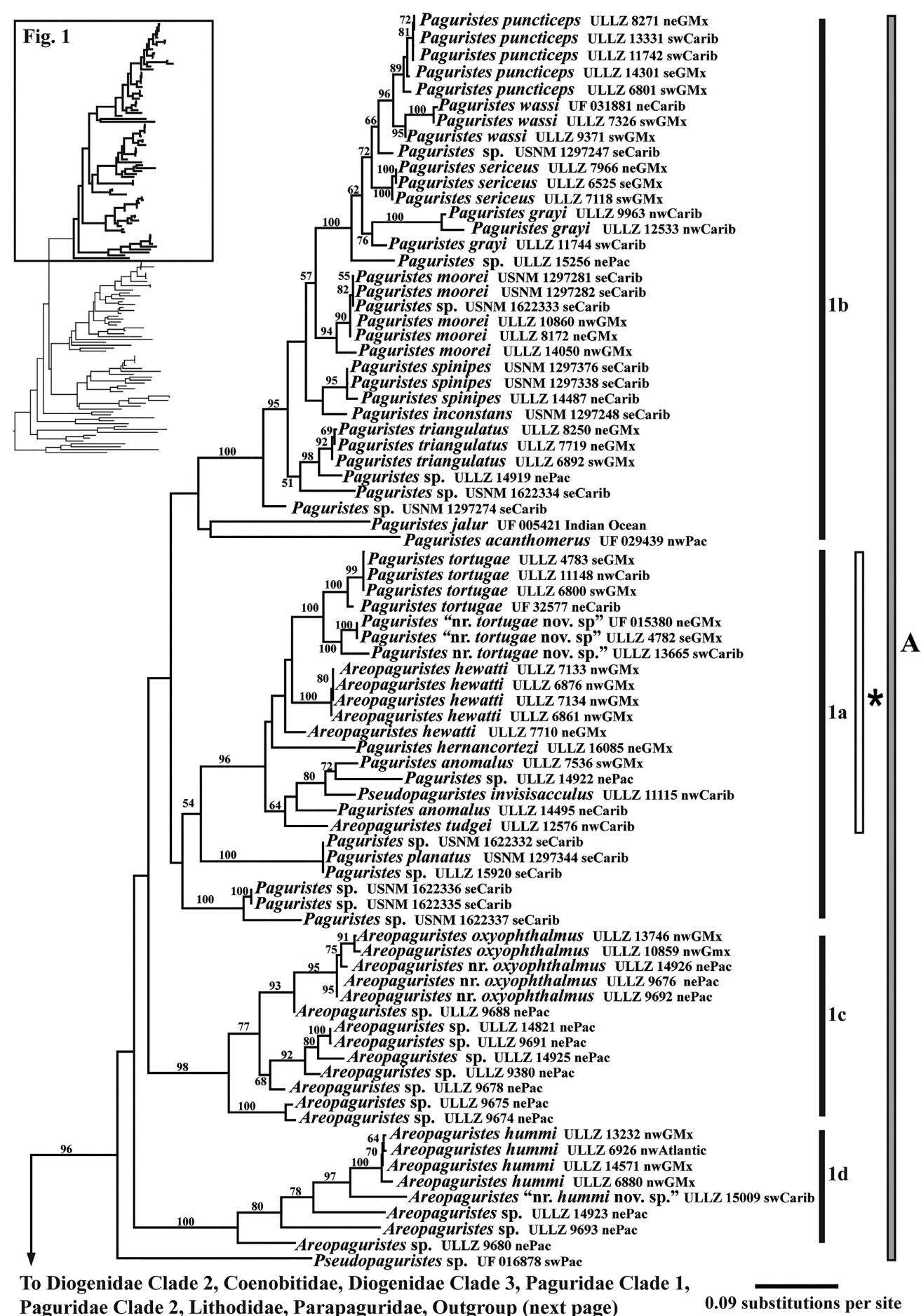

FIGURE 1. Maximum Likelihood phylogeny (-lnL: 26590.631) inferred in RAxML under the GTR + Gamma model of nucleotide substitution. Bootstrap proportions resulting from 1000 bootstrap replicates are displayed at tree nodes, with values under 50 omitted. Branch lengths are measured as substitutions per site. A) denotes Diogenidae Clade 1, with subdivisions 1a, 1b, 1c, and 1d. An asterisk (*) denotes the Paguristes tortugae complex. B) denotes Paguridae Clade 1. C) denotes Lithodidae. D) denotes Paguridae Clade 2. E) denotes Diogenidae Clade 2. F) denotes Coenobitidae. G) denotes Diogenidae Clade 3. H) denotes the family Parapaguridae. For branch labels, taxon name is followed by voucher catalog number and abbreviated collection locality (Table 1). Abbreviations: nwAtlantic = northwestern Atlantic; neCarib = northeastern Caribbean; nwCarib = northwestern Caribbean; seCarib = southeastern Caribbean; swCarib = southwestern Caribbean; neGMx = northeastern Gulf of Mexico; nwGMx = northwestern Gulf of Mexico; seGMx = southeastern Gulf of Mexico; swGMx = southwestern Gulf of Mexico; $n e P a c=$ northeastern Pacific; $w$ Pac $=$ western Pacific; $n w P a c=$ northwestern Pacific; sePac $=$ southeastern Pacific; swPac $=$ southwestern Pacific. 

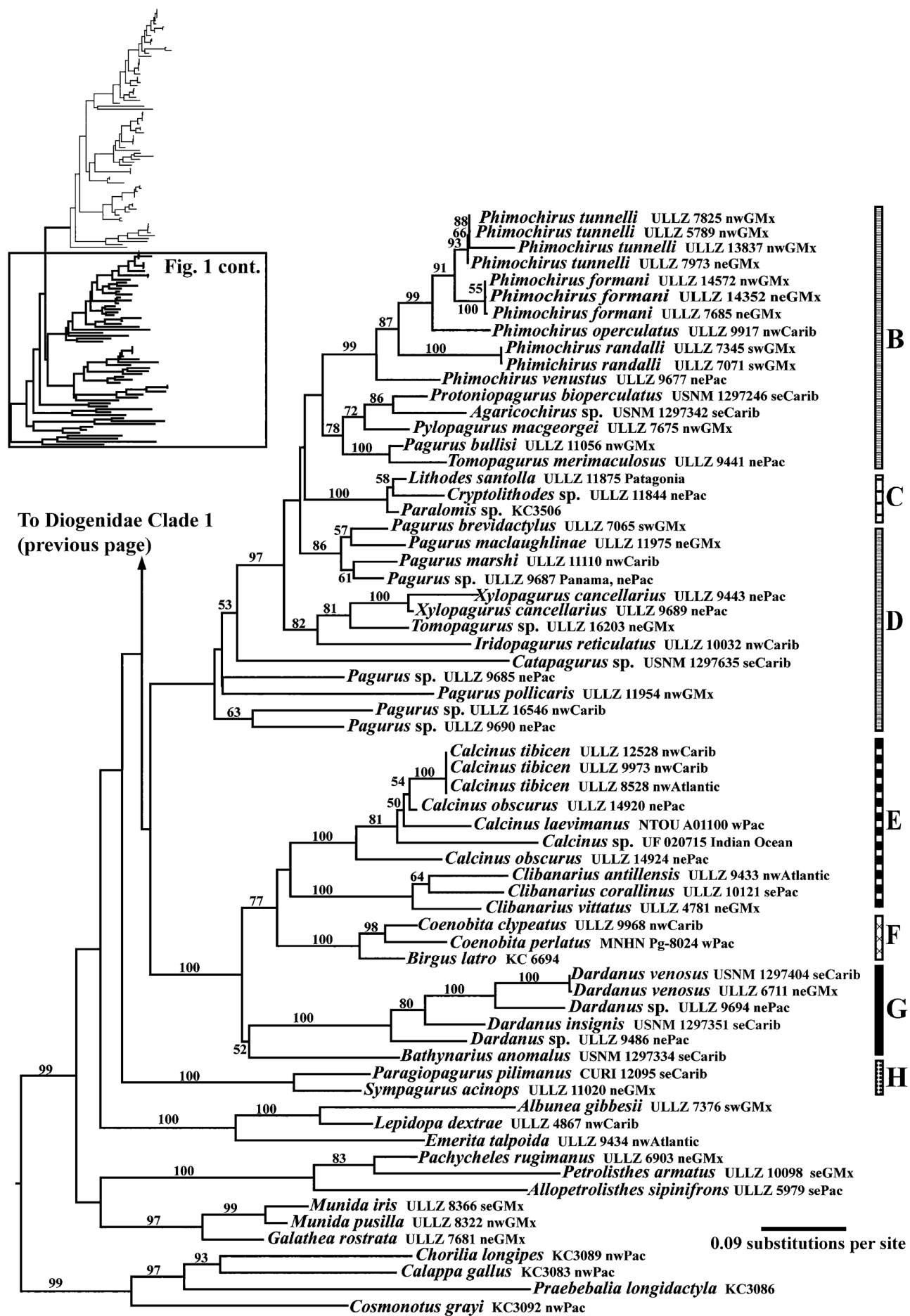

FIGURE 1 (cont'd). Maximum Likelihood phylogeny (-lnL: 26590.631) inferred in RAxML under the GTR + Gamma model of nucleotide substitution. Bootstrap proportions resulting from 1000 bootstrap replicates are displayed at tree nodes, with values under 50 omitted. Branch lengths are measured as substitutions per site. A) denotes Diogenidae Clade 1, with subdivisions 1a, 1b, 1c, and 1d. An asterisk (*) denotes the Paguristes tortugae complex. B) denotes Paguridae Clade 1. C) denotes Lithodidae. D) denotes Paguridae Clade 2. E) denotes Diogenidae Clade 2. F) denotes Coenobitidae. G) denotes Diogenidae Clade 3. H) denotes the family Parapaguridae. For branch labels, taxon name is followed by voucher catalog number and abbreviated collection locality (Table 1). Abbreviations: nwAtlantic = northwestern Atlantic; neCarib = northeastern Caribbean; nwCarib $=$ northwestern Caribbean; seCarib $=$ southeastern Caribbean; swCarib $=$ southwestern Caribbean; neGMx = northeastern Gulf of Mexico; nwGMx = northwestern Gulf of Mexico; seGMx = southeastern Gulf of Mexico; swGMx = southwestern Gulf of Mexico; nePac $=$ northeastern Pacific; $w P a c=$ western Pacific; $n w P a c=$ northwestern Pacific; $s e P a c=$ southeastern Pacific; swPac $=$ southwestern Pacific. 
unknown identity from the eastern Pacific (Subclade 1d, bootstrap 100). The second major diogenid clade, Diogenidae Clade 2, counted among its constituent genera Clibanarius and Calcinus and showed significant support for a sister relationship to our representatives of Coenobitidae, Coenobita clypeatus and Birgus latro (bootstrap 77). However, Diogenidae Clade 2 was not supported as an independent clade. Comprised of the genera Bathynarius and Dardanus, Diogenidae Clade 3 showed significant bootstrap support individually (bootstrap 52) and a significantly supported sister relationship to a clade combining Diogenidae Clade 2 and Coenobitidae (bootstrap 100). When Diogenidae Clade 2, Coenobitidae, and Diogenidae Clade 3 were considered together as a monophyletic clade, that grouping was sister to a monophyletic clade composed of Paguridae Clade 1, Lithodidae, and Paguridae Clade 2, although bootstrap support for the relationship was not significant (Fig. 1). The multigene ML analysis did not recover a monophyletic Areopaguristes, and hypothetical trees that included such a clade were refuted by quantitative comparisons (Table 3).

For the evaluation of hypothetical relationships among major paguroid clades by the AU, KH, and SH tests, a $p$-value between 0 and 1 was generated for each tree inferred under topological constraints defined by us a priori. Constraints were chosen that specified genetic relatedness congruent with current paguroid taxonomy or speculated relationships among paguroid groups of various taxonomic levels. The $\mathrm{AU}, \mathrm{SH}$, and $\mathrm{KH}$ tests yielded low $p$-values for our constraint trees (Table 3) and showed that none were likely to be the "true" tree (Shimodaira 1999, 2002). This underscored the outcome of our unconstrained ML analysis that indicated a lack of monophyly for several accepted paguroid groups corresponding to clades incorporated into our constraint trees (Fig. 1).

\section{Discussion}

Diogenidae has been considered by many authors to be a monophyletic family closely allied with or sister to Coenobitidae (MacDonald et al. 1957; McLaughlin 1983, 2002; Cunningham et al. 1992; McLaughlin \& Lemaitre 1997; Forest \& McLaughlin 2000; Ahyong \& O’Meally 2004; McLaughlin et al. 2007, 2010; De Grave et al. 2009; Schnabel et al. 2009), but evidence from phylogenetic studies ranging across Decapoda suggests that the family Diogenidae may not be monophyletic (Tudge 1997; Tsang et al. 2008, 2011; Bybee et al. 2011; Schnabel et al. 2011; Bracken-Grissom et al. 2013; Landschoff \& Gouws 2018; Tan et al. 2018; Wolfe et al. 2019). Our analysis concurs with the latter findings of a non-monophyletic Diogenidae by recovering a clade that integrates the diogenid genera Bathynarius, Calcinus, Clibanarius, and Dardanus with the coenobitid genera Birgus and Coenobita (bootstrap 100) while relegating all species of Areopaguristes, Paguristes, and Pseudopaguristes to Diogenidae Clade 1 (Fig. 1). While the phylogenetic validity of these two major clades in our study and others is strongly supported, their generic composition is not congruent with currently accepted taxonomy for Paguroidea, but determination of appropriate revisions at the family level remains beyond the scope of the present study. Therefore, the clade nomenclature here employed maintains Coenobita clypeatus and Birgus latro as members of Coenobitidae, while designating the diogenid clades most closely associated with Coenobitidae as two independent subgroups of diogenid genera: Diogenidae Clade 2 (Calcinus, Clibanarius) and Diogenidae Clade 3 (Bathynarius, Dardanus).

With regard to the phylogenetic validity of Diogenidae Clade 1, Clade 2, and Clade 3, our outcomes mirror those from a molecular ML analysis of Anomura by Bracken-Grissom et al. (2013) that included 66 paguroids and recovered an assemblage of diogenid hermit crabs with a generic constituency consistent with our Diogenidae Clade 1. Although not addressed in detail by that study, an additional finding by Bracken-Grissom et al. (2013) was a significantly supported (bootstrap 100) assemblage of 16 species corresponding to an assemblage from our analysis in which Diogenidae Clade 2, Coenobitidae, and Diogenidae Clade 3 are united (bootstrap 100). Additional support for our three diogenid clades can be found in a recent CO1 barcoding study (Landschoff \& Gouws 2018). That study recovered a polyphyletic Diogenidae having three groupings with constituencies congruent with those of our three diogenid clades. The convergence of our phylogenetic analysis with some previous studies provides ample justification for our evaluation of the phylogenetic status of Diogenidae, refuting the hypothesis of a monophyletic Diogenidae by three metrics (Table 3). Nonetheless, it is important to acknowledge that the taxonomic sampling of Paguroidea in our study, as well as those cited, was limited and that taxonomic under-sampling can cause errors in the accuracy of phylogenetic inference (Zwickl \& Hillis 2002; Hillis et al. 2003; Weins 2003). Thus, further work with more robust taxonomic coverage is necessary to clarify foundational relationships among paguroid genera and families. 
Phylogenetic results presented herein reveal potential trends in morphology and generic constituency across the four subclades within Diogenidae Clade 1 (Fig. 1). Among these subclades, Subclade 1a includes the Paguristes tortugae complex, a group established herein as having constituent species that are by varied authors assigned to Paguristes, Pseudopaguristes, or Areopaguristes, while a second subclade, Subclade 1b, encompasses only species of Paguristes. Two other assemblages, Subclade 1c and Subclade 1d, count only species of Areopaguristes as constituents. Correlations between the telson groupings applied to the genus Paguristes by McLaughlin \& Provenzano (1975) and some Diogenidae Clade 1 genetic subclades are evident in the present study, with most species included in the monophyletic Subclade 1b belonging to the group of Paguristes spp. with unarmed telsons (Fig. 2A). However, no similar monophyletic genetic grouping in our analysis corresponds to the morphologically defined group with armed telsons (Fig. 2B). The correspondence of telson morphology to at least part of our molecular phylogenetic findings suggests that, beyond its utility in species diagnosis within Paguristes, Areopaguristes, and Pseudopaguristes, telson armature could prove to be of value in future generic level revisions in this group (McLaughlin \& Provenzano 1975; Miyake 1978; Komai 2001; McLaughlin \& Rahayu 2005; Rahayu 2006; Rahayu \& McLaughlin 2006; McLaughlin 2008; Lemaitre \& Felder 2012; Komai et al. 2015).
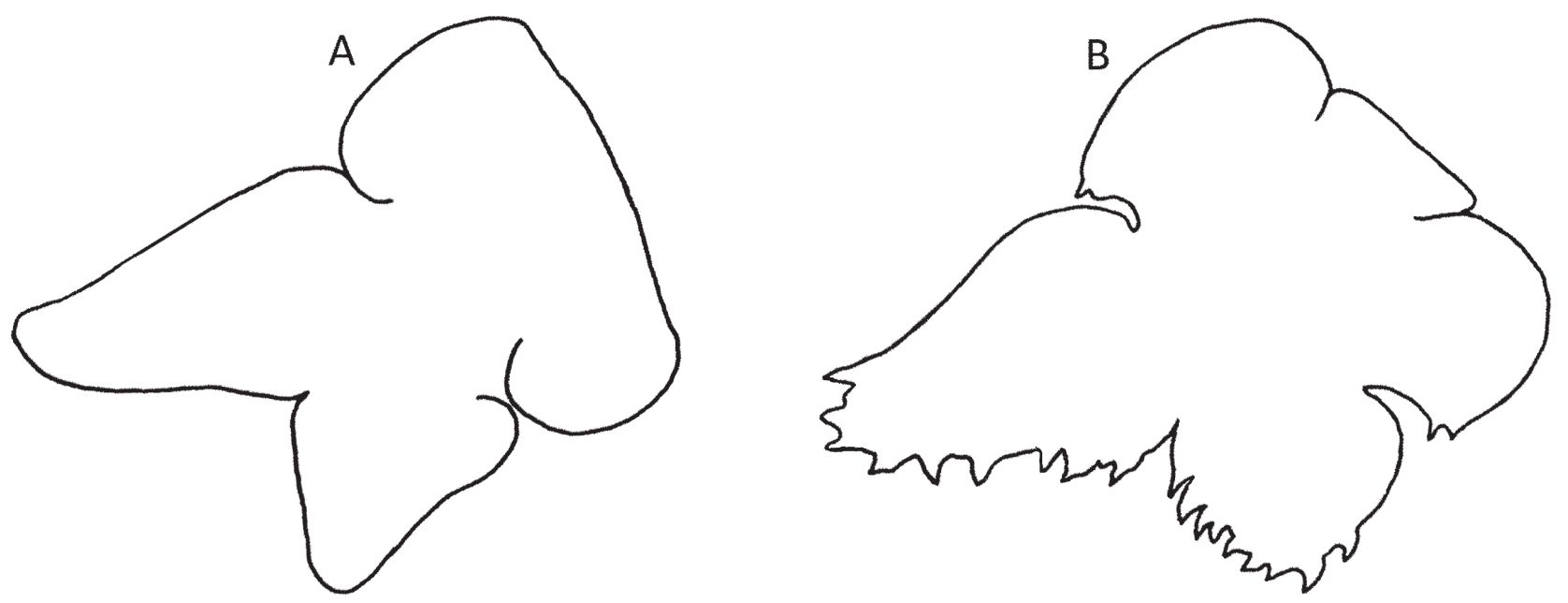

FIGURE 2. Schematic illustrations of unarmed (A) and armed (B) telsons.

In contrast to a recent finding that would place a monophyletic Paguristes as sister to Areopaguristes and Pseudopaguristes (Landschoff \& Gouws 2018), our unconstrained ML phylogeny reveals that species presently assigned to the genus Areopaguristes on the basis of gill formula do not form a monophyletic grouping within the P. tortugae complex, nor within other subclades of Diogenidae Clade 1 (Fig. 1). The results of the KH, SH, and AU tests provide substantial quantitative support for the distribution of species assigned to Areopaguristes, Pseudopaguristes, and Paguristes, as currently recognized, throughout multiple genetic subclades within Diogenidae Clade 1. The $p$-values refute the general monophyly of Areopaguristes, as well as the hypothesis that Paguristes and Areopaguristes are reciprocally monophyletic sister clades (Table 3). This lack of support for generic monophyly has important implications for the taxonomic status of all three genera, as it demonstrates that gill formula similarities likely represent little more than convergent evolution among subgroups presently assigned to Paguristes, Areopaguristes, and Pseudopaguristes. Thus, among the extensively represented western Atlantic members in our phylogenetic analyses that are presently treated under these genera there is no more justification for assignment of some to the otherwise western Pacific genera Areopaguristes or Pseudopaguristes than there is for them to for now remain in Paguristes. Indeed, the single western Pacific "Pseudopaguristes sp." in our analysis, likely an undescribed species, is well separated from any western Atlantic species that might be currently treated under that genus on the basis of its gill formula.

From the results of this study, specific taxonomic revisions of Areopaguristes, Paguristes, and Pseudopaguristes cannot be proposed but the genetic breaks within and among the three genera indicate that taxonomic revisions will be necessary if paguroid taxonomy is to reflect evolutionary relationships. For Paguristes, Areopaguristes, and Pseudopaguristes, one approach to revisions would be to subdivide the existing genera and redistribute the constituent species among new genera erected to reflect phylogenetic relationships. Such an undertaking would likely yield several genera and morphological characters will play a key role in determining the scope of those proposed genera. 
Results reported herein and preliminary results from a broader genetic analysis currently underway support this approach, indicating that character suites applied currently to some informal species complexes correspond to distinct genetic subclades in several cases. An alternative approach would be the treatment of Paguristes, Areopaguristes, and Pseudopaguristes as a single large genus of more than 200 species. This approach avoids the establishment new genera and the introduction of potentially confounding taxonomic complexity but would limit the utility of the necessarily broad morphological diagnosis that would accompany such a revision.

Establishing the limits of Paguristes s.s. is clearly required in the course of eventual generic revisions to the diogenids, which is beyond the scope of the present study. With the eastern Pacific Paguristes hirtus Dana, 1851, as the type of the genus, we find no compelling reason to reject the conclusion by Haig (1955) that it was a junior synonym of $P$. weddellii $\mathrm{H}$. Milne Edwards, 1848. This synonymy was called into question by Ayon-Parente \& Hendrickx (2013), who regarded $P$. hirtus and $P$. weddellii to be separate species, of which the latter was moved to Tetralobistes Ayon-Parente \& Hendrickx, 2010. We currently lack adequate sequence-quality materials of $P$. weddellii to fully address its relationships in our molecular phylogenetic tree, but strongly suspect it to be most closely affiliated with Subclade 1d, otherwise comprised of Areopaguristes spp. from the western Atlantic and eastern Pacific.

This is suggested on the basis of readily evident morphological similarities between species of the A. hummi complex and $P$. weddelli, as well as incomplete sequence comparisons, both of which will be addressed in a coming paper (Craig et al., in preparation).

The internal structure of the genetic clade encompassing species assignable to the Paguristes tortugae complex shows significant support for a previously unrecognized cryptic species close to $P$. tortugae (Fig. 1). Well prior to present genetic evidence for this new species, freshly collected specimens could be designated as one of two distinct color forms that were otherwise both assignable to P. tortugae by diagnostic morphology (Provenzano 1959, 1965; Williams 1965; McLaughlin \& Provenzano 1974; Strasser \& Price 1999). In the description of $P$. tortugae little mention was made of color (Schmitt 1933), and subsequent descriptions of preserved $P$. tortugae specimens described them as "colorless" (Holthuis 1959), "whitish" (Provenzano 1959, Williams 1965), or "straw colored" (McLaughlin \& Provenzano 1974). Some accounts detailed prominent red spines on the mesial margin of the manus and carpus of the cheliped (Provenzano 1959; Holthuis 1959; Williams 1965). Others described "pinkish legs" (Holthuis 1959) or purple to reddish legs (Provenzano 1965). Most accounts agreed that the eyestalks and antennular peduncles of $P$. tortugae bore dark bands near mid-length, visible in life and in preservation (Wass 1955; Holthuis 1959; Provenzano 1959, 1965; Williams 1965; McLaughlin \& Provenzano 1974; Strasser \& Price 1999). It was accepted that color varied in live examples of the species (Provenzano 1965; McLaughlin \& Provenzano 1974; Williams 1965), with lighter colored variants of P. tortugae reportedly comparable to A. hewatti (Wass 1963; McLaughlin \& Provenzano 1974). From comparison among photographic accounts of voucher specimens of $A$. hewatti, $P$. tortugae, and our cryptic $P$. nr. tortugae, one set of specimens morphologically attributable to $P$. tortugae shows some similarity in color to $A$. hewatti. This set of specimens, with background color generally pale rose to buff, is regarded by us to represent $P$. tortugae s.s. A second set of specimens bears more similarity to a previously noted but undescribed species close to P. tortugae (Strasser \& Price 1999), and is perhaps representative of the "darker" forms of P. tortugae noted by McLaughlin \& Provenzano (1974). This second color-form, with a tan to olive background color marked by vibrant red spines on the carpi of the chelipeds and pereopods, is regarded by us to be a cryptic species herein labelled as $P$. nr. tortugae. Three individuals of this putative new species are included in our analysis, and together they form a monophyletic clade with high bootstrap support (bootstrap 100). Equally high bootstrap support links our cryptic species to $P$. tortugae s.s., confirming the two as genetically distinct sister lineages (bootstrap 100). While recorded variation in color within $P$. tortugae s.l. was previously suggested to be an ecomorphic variant correlated with substrate color (McLaughlin \& Provenzano 1974), the molecular evidence presented here demonstrates a clear correspondence between color variation and genetic divergence in the case of these species. Minor differences in morphology also support the separation, but full comparative treatment of this and color characters is deferred to a companion paper formally describing $P$. nr. tortugae as a new species (Craig \& Felder, in preparation).

Areopaguristes hummi and several eastern Pacific allies form a well-supported clade (bootstrap 100), but the close affinity of that group with the rest of Diogenidae Clade 1 is insignificantly supported. In our ML phylogeny, the A. hummi complex includes specimens with unclear diagnoses, many of which are from the Pacific coast of Panama. With these unidentified Pacific specimens included, the $A$. hummi complex is strongly monophyletic (bootstrap 100). Multiple individuals of $A$. hummi s.s. from the Gulf of Mexico cluster together with high support (boot- 
strap 100), and A. nr. hummi, our new species from Atlantic coast of Central America, is sister to our assemblage of A. hummi s.s. representatives (bootstrap 97).

Definitive morphological characters for $A$. nr. hummi are not readily apparent, but support for its separation is found in the coloration of fresh specimens. As described by Wass (1955), A. hummi s.s. is characterized by a vibrant blue patch on the distal portion of the chelar merus mesial face, bounded anteriorly by a well-defined, curved, black marking (the "meral rainbow"). Areopaguristes nr. hummi lacks this blue patch, and the black patterning seen on the mesial face of the merus is restricted to a well-defined, crescent shaped marking at the distal margin (the "meral crescent"). Other differences are apparent in the coloration of the head appendages, predominantly the ocular peduncles, which exhibit a golden color in $A$. nr. hummi, in contrast to the blue hue of $A$. hummi s.s. Adding support for the establishment of $A$. nr. hummi, the geographic distribution for the two species does not overlap. Areopaguristes hummi s.s. is found broadly across the Gulf of Mexico (Wass 1955; Strasser \& Price 1999; Felder et al. 2009a), while our new species, $A$. nr. hummi, is currently known only from the Atlantic coast of Central America. As with $P$. nr. tortugae, full comparative treatment of morphology and color characters is deferred to a companion paper formally describing $A$. nr. hummi as a new species (Craig \& Felder, in preparation).

The phylogenetic inference presented here demonstrates the potential for color and pattern to predict broader clade composition for species of the $P$. tortugae complex. This becomes evident when trends in head appendage color and pattern are superimposed on our phylogenetic analysis. In the phylogenetic analysis, the core of the $P$. tortugae complex is divided into two primary clades. One of these, consisting of P. tortugae, P. nr. tortugae, A. hewatti, and $P$. hernancortezi, encompasses only species with banded or spotted eyestalks. In the other subclade, composed of Aeropaguristes tudgei, Pseudopaguristes invisisacculus, and Paguristes anomalus all species have blue head appendages and distally blue eyestalks. In this case, three species currently treated in three different genera on the basis of supposedly fundamental differences in gill formula, are instead grouped by eyestalk color in conformation with their molecular genetic clade grouping. Species of the Paguristes tortugae complex not included in our molecular analysis can be speculatively placed according to this trend, with P. zebra as a potential constituent of the banded eyestalk clade, while $P$. scarabinoi falls among the species with blue head appendages. The qualitative nature of using eyestalk patterning and color to delineate subclades within the $P$. tortugae complex limits definitive conclusions about subclade constituency, but evidence of this phenomenon all the more compels hermit crab systematists to include color of fresh specimens as a character of potential value not only for species distinctions but for determination of phylogenetic groupings of species as well.

\section{Acknowledgements}

For assisting with access to comparative materials for this study, we thank K. Reed, S. Pecnik, and other support staff of the Department of Invertebrate Zoology, National Museum of Natural History, Smithsonian Institution, Washington, D.C., along with M. Bemis and G. Paulay, Florida Natural History Museum, University of Florida, Gainesville. We also thank R. Lemaitre for his advice and commentary throughout our preparation of this manuscript. Among many colleagues who assisted with field sampling, logistics, and analyses, we thank F. Álvarez, C. Baldwin, H. Bracken-Grissom, R. Collin, E. Escobar, J. Felder, S. Fredericq, E. Garcia, S. Jones, F. Mantelatto, E. Palacios-Theil, V. Paul, S. Pecnik, S. Rabalais, R. Robles, W. Schmidt, J. Scioli, B. Thoma, and A. Windsor. Work was supported by funding to DLF from the U.S. National Science Foundation grants NSF/BS\&I DEB-0315995, NSF/AToL EF-0531603, and NSF/RAPID DEB 1045690, along with U.S. Department of Energy grant no. DEFG02-97ER1220. This is UL Lafayette Laboratory for Crustacean Research contribution number 213 and Smithsonian Caribbean Coral Reef Ecosystems Program contribution number 1042.

\section{References}

Abele, L.G. \& Kim, W. (1986) An illustrated guide to the marine decapod crustaceans of Florida. Florida Department of Environmental Regulation, Technical Series, 8 (1), Parts 1, 2, 1-760.

Ahyong, S.T. \& O'Meally, D. (2004) Phylogeny of the Decapoda Reptantia: resolution using three molecular loci and morphology. Raffles Bulletin of Zoology, 52 (2), 673-693.

Ahyong, S.T., Schnabel, K.E. \& Maas, E.W. (2009) Anomuran phylogeny: New insights from molecular data. In: Martin, J.W., 
Felder, D.L. \& Crandall, K.A. (Eds.), Crustacean Issues. Vol. 18. Decapod Crustacean Phylogenetics. CRC Press, Boca Raton, Florida, pp. 391-408.

https://doi.org/10.1201/9781420092592-c20

Ahyong, S.T., Baba, K., Macpherson, E. \& Poore, G.C.B. (2010) A new classification of the Galatheoidea (Crustacea: Decapoda: Anomura). Zootaxa, 2676 (1), 57-68.

https://doi.org/10.11646/zootaxa.2676.1.4

Alfaro, M.E., Zoller, S. \& Lutzoni, F. (2003) Bayes or bootstrap? A simulation study comparing the performance of Bayesian Markov chain Monte Carlo sampling and bootstrapping in assessing phylogenetic confidence. Molecular Biology and Evolution, 20 (2), 255-266.

https://doi.org/10.1093/molbev/msg028

Anisimova, M. \& Gascuel, O. (2006) Approximate likelihood-ratio test for branches: a fast, accurate, and powerful alternative. Systematic Biology, 55 (4), 539-552. https://doi.org/10.1080/10635150600755453

Anker, A., Hurt, C. \& Knowlton, N. (2008) Revision of the Alpheus formosus Gibbes, 1850 complex, with redescription of $A$. formosus and description of a new species from the tropical western Atlantic (Crustacea: Decapoda: Alpheidae). Zootaxa, 1707 (1), 1-22. https://doi.org/10.11646/zootaxa.1707.1.1

Asakura, A. (2004) Pseudopaguristes shidarai, a new species of hermit crab (Crustacea: Decapoda: Diogenidae) from Japan, the fourth species of the genus. Proceedings of the Biological Society of Washington, 117 (1), 153-168.

Asakura, A. \& Kosuge, T. (2004) Pseudopaguristes bicolor, a new species of hermit crab (Crustacea: Decapoda: Diogenidae) from Japan, the third species of the genus. Proceedings of the Biological Society of Washington, 117 (1), 57-67.

Ayon-Parente, M. \& Hendrickx, M.E. (2013) Redescription and taxonomic status of Paguristes weddellii H. Milne Edwards, 1848 (Crustacea: Anomura: Paguroidea: Diogenidae) from the eastern Pacific. Zootaxa, 3616 (6), 587-596. https://doi.org/10.11646/zootaxa.3616.6.5

Bickford, D., Lohman, D.J., Sodhi, N.S., Ng, P.K., Meier, R., Winker, K., Ingram, K.K. \& Das, I. (2007) Cryptic species as a window on diversity and conservation. Trends in Ecology and Evolution, 22 (3), 148-155. https://doi.org/10.1016/j.tree.2006.11.004

Bracken-Grissom, H.D. \& Felder, D.L. (2014) Provisional revision of American snapping shrimp allied to Alpheus floridanus Kingsley, 1878 (Crustacea: Decapoda: Alpheidae) with notes on A. floridanus africanus. Zootaxa, 3895 (4), $451-491$. https://doi.org/10.11646/zootaxa.3895.4.1

Bracken-Grissom, H.D., Cannon, M.E., Cabezas, P., Feldmann, R.M., Schweitzer, C.E., Ahyong, S.T. \& Crandall, K.A. (2013) A comprehensive and integrative reconstruction of evolutionary history for Anomura (Crustacea: Decapoda). BMC Evolutionary Biology, 13 (1), 1-128. https://doi.org/10.1186/1471-2148-13-128

Burton, T.E. \& Davie, P.J.F. (2007) A revision of the shovel-nosed lobsters of the genus Thenus (Crustacea: Decapoda: Scyllaridae), with descriptions of three new species. Zootaxa, 1429 (1), 1-38. https://doi.org/10.11646/zootaxa.1429.1.1

Bybee, S.M., Bracken-Grissom, H.D., Hermansen, R.A., Clement, M.J., Crandall, K.A. \& Felder, D.L. (2011) Directed next generation sequencing for phylogenetics: an example using Decapoda (Crustacea). Zoologischer Anzeiger-A Journal of Comparative Zoology, 250 (4), 497-506. https://doi.org/10.1016/j.jcz.2011.05.010

Castresana, J. (2000) Selection of conserved blocks from multiple alignments for their use in phylogenetic analysis. Molecular Biology and Evolution, 17 (1), 540-552. https://doi.org/10.1093/oxfordjournals.molbev.a026334

Castro, P. (1982) Notes on symbiotic decapod crustaceans from Gorgona Island, Colombia, with a revision of the eastern Pacific species of Trapezia (Brachyura: Xanthidae), symbionts of scleractinian corals. Anales del Instituto de Investigaciones Marinas de Punta Betín, 12, 9-17. https://doi.org/10.25268/bimc.invemar.1982.12.0.490

Chenari, F., Nabavi, M.B., Salari, M.A., Savari, A. \& Zolgharnein, H. (2017) Identifying color morphotypes of the species Leptodius exaratus (Brachyuran: Xanthidae) based on the molecular and electron microscopy studies. Iranian Fisheries Science Journal, 26 (3), 139-148.

Chernomor, O., von Haeseler, A. \& Minh, B.Q. (2016) Terrace aware data structure for phylogenomic inference from supermatrices. Systematic Biology, 65 (6), 997-1008. https://doi.org/10.1093/sysbio/syw037

Cunningham, C.W., Blackstone, N.W. \& Buss, L.W. (1992) Evolution of king crabs from hermit crab ancestors. Nature, 355 (6360), 539-542. https://doi.org/10.1038/355539a0

Dana, J.D. (1851) Conspectus of the Crustacea of the U.S. Exploring Expedition-Paguridea. Proceedings of the Academy of Natural Sciences of Philadelphia, 5, 267-272.

da Silva, J.M., Creer, S., Dos Santos, A., Costa, A.C., Cunha, M.R., Costa, F.O. \& Carvalho, G.R. (2011) Systematic and evolutionary insights derived from mtDNA COI barcode diversity in the Decapoda (Crustacea: Malacostraca). PloS One, 6 (5), 
e19449.

https://doi.org/10.1371/journal.pone.0019449

Davie, P.J.F., Shih, H.T. \& Chan, B.K.K. (2010) A new species of Mictyris (Decapoda, Brachyura, Mictyridae) from the Ryukyu Islands, Japan. Crustaceana Monographs, 11, 83-105.

https://doi.org/10.11646/zootaxa.3686.1.3

De Grave, S., Pentcheff, N.D., Ahyong, S.T., Chan, T.Y., Crandall, K.A., Dworschak, P.K., Felder, D.L., Feldmann, R.M., Fransen, C.H.J.M., Goulding, L.Y.D., Lemaitre, R., Low, M.E.Y., Martin, J.W., Ng, P.K.L., Schweitzer, C.E., Tan, S.H., Tshudy, D. \& Wetzer, R. (2009) A classification of living and fossil genera of decapod crustaceans. Raffles Bulletin of Zoology, Supplement 21, 1-109.

Dixon, C.J., Ahyong, S.T. \& Schram, F.R. (2003) A new hypothesis of decapod phylogeny. Crustaceana, 76 (8), $935-975$. https://doi.org/10.1163/156854003771997846

Efron, B., Halloran, E. \& Holmes, S. (1996) Bootstrap confidence levels for phylogenetic trees. Proceedings of the National Academy of Sciences, 93 (23), 13429-13429. https://doi.org/10.1073/pnas.93.23.13429

Felder, D.L. (1973) An annotated key to crabs and lobsters (Decapoda, Reptantia) from coastal waters of the northwestern Gulf of Mexico. Publications of the Center for Wetland Resources, LSU-SG-73-02, 1-103.

Felder, D.L, Álvarez, F., Goy, J.W. \& Lemaitre, R. (2009a) Decapoda (Crustacea) of the Gulf of Mexico, with comments on the Amphionidacea. In: Felder, D.L. \& Camp, D.K. (Eds.), Gulf of Mexico Origin, Waters, and Biota. Vol. 1. Biodiversity. Texas A\&M University Press, College Station, pp. 1019-1104.

Felder, D.L., Dworschak, P.C., Robles, R., Bracken, H.D., Windsor, A.M., Felder, J.M. \& Lemaitre, R. (2009b) Obvious invaders and overlooked infauna: unexpected constituents of the decapod crustacean fauna at Twin Cays, Belize. Smithsonian Contributions to the Marine Sciences, 38, 181-188.

Felder, D.L., Lemaitre, R. \& Craig, C. (2019) Two new species of the Phimochirus holthuisi complex from the Gulf of Mexico, supported by morphology, color, and genetics (Crustacea: Anomura: Paguridae). Zootaxa, 4683 (4), 531-551. https://doi.org/10.11646/zootaxa.4683.4.4

Felsenstein, J. (1985) Confidence limits on phylogenies: an approach using the bootstrap. Evolution, 39 (4), $783-791$. https://doi.org/10.1111/j.1558-5646.1985.tb00420.x

Forest, J. (1987) Les Pylochelidae ou "Pagures symetriques" (Crustacea Coenobitoidea). In: Résultats des campagnes MUSORSTOM. Mémoires du Muséum National d'Histoire Naturelle, Série A, Zoologie, 137, 1-254.

Forest, J. \& McLaughlin, P.A. (2000) Superfamily Coenobitoidea, families Pylochelidae and Diogenidae. In: Forest, J., de Saint Laurent, M., McLaughlin, P.A. \& Lemaitre, R. (Eds.), The Marine Fauna of New Zealand: Paguridea (Decapoda: Anomura) exclusive of the Lithodidae. NIWA Biodiversity Memoir, 114, pp. 31-103.

Galtier, N. (2004) Sampling properties of the bootstrap support in molecular phylogeny: influence of nonindependence among sites. Systematic Biology, 53 (1), 38-46. https://doi.org/10.1080/10635150490264680

Grippa, G.B. \& d'Udekem d'Acoz, C. (1996) The genus Periclimenes Costa, 1844 in the Mediterranean Sea and the northeastern Atlantic Ocean: review of the species and description of Periclimenes sagittifer aegylios subsp. nov. (Crustacea, Decapoda, Caridea, Pontoniinae). Atti della Società Italiana di Scienze naturali e del Museo Civico di Storia naturale di Milano, 135, 401-412.

Haig, J. (1955) Reports of the Lund University Chile Expedition 1948-49. 20. The Crustacea Anomura of Chile. Lunds Universitets Arsskrif, Series 2, 51 (12), 1-68.

Haig, J. \& McLaughlin, P.A. (1983) New Calcinus species (Decapoda: Anomura: Diogenidae) from Hawaii, with a key to the local species. Micronesica, 9 (1-2), 107-121.

Hedges, S.B. (1992) The number of replications needed for accurate estimation of the bootstrap P value in phylogenetic studies. Molecular Biology and Evolution, 9 (2), 366-369.

Hiller, A., Kraus, H., Almon, M. \& Werding, B. (2006) The Petrolisthes galathinus complex: Species boundaries based on color pattern, morphology and molecules, and evolutionary interrelationships between this complex and other Porcellanidae (Crustacea: Decapoda: Anomura). Molecular Phylogenetics and Evolution, 40 (2), 547-569. https://doi.org/10.1016/j.ympev.2006.03.030

Hiller, A. \& Werding, B. (2019) A new species of Petrolisthes (Crustacea, Anomura, Porcellanidae) inhabiting vermetid formations (Mollusca, Gastropoda, Vermetidae) in the southern Caribbean Sea. ZooKeys, 876, 143-151. https://doi.org/10.3897/zookeys.876.37244

Hillis, D.M. \& Bull, J.J. (1993) An empirical test of bootstrapping as a method for assessing confidence in phylogenetic analysis. Systematic Biology, 42 (2), 182-192. https://doi.org/10.1093/sysbio/42.2.182

Hillis, D.M., Pollock, D.D., McGuire, J.A. \& Zwickl, D.J. (2003) Is sparse taxon sampling a problem for phylogenetic inference? Systematic Biology, 52 (1), 124-126. https://doi.org/10.1080/10635150390132911

Holthuis, L.B. (1959) The Crustacea Decapoda of Suriname (Dutch Guiana). Zoologische Verhandelingen, 44, 1-296.

Hultgren, K.M., Hurt, C. \& Anker, A. (2014) Phylogenetic relationships within the snapping shrimp genus Synalpheus (Decapoda: Alpheidae). Molecular Phylogenetics and Evolution, 77, 116-125. 
https://doi.org/10.1016/j.ympev.2014.03.008

Jung, J., Park, J.H. \& Kim, W. (2018) A Systematic Study on the Paguroidea (Crustacea: Decapoda) in South Korean water: checklist and geographical distribution. Ocean and Polar Research, 40 (3), 145-160. [in Korean]

Katoh, K., Misawa, K., Kuma, K.I. \& Miyata, T. (2002) MAFFT: a novel method for rapid multiple sequence alignment based on fast Fourier transformations. Nucleic Acids Research, 30 (14), 3059-3066. https://doi.org/10.1093/nar/gkf436

Keiler, J., Wirkner, C.S. \& Richter, S. (2017) One hundred years of carcinization-the evolution of the crab-like habitus in Anomura (Arthropoda: Crustacea). Biological Journal of the Linnean Society, 121 (1), 200-222. https://doi.org/10.1093/biolinnean/blw031

Kishino, H. \& Hasegawa, M. (1989) Evaluation of the maximum likelihood estimate of the evolutionary tree topologies from DNA sequence data, and the branching order in Hominoidea. Journal of Molecular Evolution, 29 (2), 170-179.

Knowlton, N. (1986) Cryptic and sibling species among the decapod Crustacea. Journal of Crustacean Biology, 6 (3), $356-$ 363. https://doi.org/10.2307/1548175

Knowlton, N. (2000) Molecular genetic analyses of species boundaries in the sea. In: Sol'e-Cava, A.M., Russo, C.A.M. \& Thorpe, J.P. (Eds.), Marine genetics. Hydrobiologia, 420, pp. 73-90. https://doi.org/10.1007/978-94-017-2184-4_8

Knowlton, N. \& Mills, D.E.K. (1992) The systematic importance of color and color pattern: evidence for complex of sibling species of snapping shrimp (Caridea: Alpheidae: Alpheus) from the Caribbean and Pacific coasts of Panama. Proceedings of the San Diego Society of Natural History, 8, 1-5.

Komai, T. (2001) A review of the north-western Pacific species of the genus Paguristes (Decapoda: Anomura: Diogenidae), I. Five species initially reported by Ortmann (1892) from Japan. Journal of Natural History, 35 (3), 357-428. https://doi.org/10.1080/002229301300009603

Komai, T. (2009) A review of the northwestern Pacific species of the genus Paguristes (Decapoda: Anomura: Diogenidae). II. Species transferred to the genus Stratiotes, with descriptions of two new species. Natural History Research, 10 (2), 59-92.

Komai, T., Reshmi, R. \& Kumar, A.B. (2015) A new species of the hermit crab genus Paguristes Dana, 1851 (Crustacea: Decapoda: Anomura: Diogenidae) from southwestern India. Zootaxa, 3937 (3), 517-532. https://doi.org/10.11646/zootaxa.3937.3.5

Landschoff, J. \& Gouws, G. (2018) DNA barcoding as a tool to facilitate the taxonomy of hermit crabs (Decapoda: Anomura: Paguroidea). Journal of Crustacean Biology, 38 (6), 780-793. https://doi.org/10.1093/jcbiol/ruy084

Lemaitre, R. \& Felder, D.L. (2012) A new species of the hermit crab genus Areopaguristes Rahayu \& McLaughlin, 2010 (Crustacea: Decapoda: Anomura: Diogenidae) discovered in the Mesoamerican Barrier Reef of Belize, Caribbean Sea. Zootaxa, $3480(1), 67-79$. https://doi.org/10.11646/zootaxa.3480.1.3

Lemaitre, R. \& McLaughlin, P. (2020) World Paguroidea \& Lomisoidea database. Paguroidea Latreille, 1802. World Register of Marine Species. Available from: http://marinespecies.org/aphia.php?p=taxdetails\&id=106687 (accessed 14 August 2020)

Lemaitre, R., Rahayu, D.L. \& Komai, T. (2018) A revision of "blanket-hermit crabs" of the genus Paguropsis Henderson, 1888, with the description of a new genus and five new species (Crustacea, Anomura, Diogenidae). ZooKeys, 752, 17-97. https://doi.org/10.3897/zookeys.752.23712

Lemoine, F., Entfellner, J.B.D., Wilkinson, E., Correia, D., Felipe, M.D., De Oliveira, T. \& Gascuel, O. (2018) Renewing Felsenstein's phylogenetic bootstrap in the era of big data. Nature, 556 (7702), 452-456. https://doi.org/10.1038/s41586-018-0043-0

MacDonald, J.D., Pike, R.B. \& Williamson, D.I. (1957) Larvae of the British species of Diogenes, Pagurus, Anapagurus and Lithodes (Crustacea, Decapoda). Proceedings of the Zoological Society of London, 128 (2), 209-258. https://doi.org/10.1111/j.1096-3642.1957.tb00265.x

Macpherson, E. \& Machordom, A. (2001) Phylogenetic relationships of species of Raymunida (Decapoda: Galatheidae) based on morphology and mitochondrial cytochrome oxidase sequences, with the recognition of four new species. Journal of Crustacean Biology, 21 (3), 696-714. https://doi.org/10.1163/20021975-99990168

Maddison, W.P. \& Maddison, D.R. (2017) Mesquite: a modular system for evolutionary analysis. Version 3.2. Available from: http://mesquiteproject.org (accessed 14 June 2021)

Malay, M.C.M.D. \& Paulay, G. (2010) Peripatric speciation drives diversification and distributional pattern of reef hermit crabs (Decapoda: Diogenidae: Calcinus). Evolution, 64 (3), 634-662. https://doi.org/10.1111/j.1558-5646.2009.00848.x

Malay, M.C.M.D., Rahayu, D.L. \& Chan, T.Y. (2018) Hermit crabs of the genera Calcinus Dana, Clibanarius Dana, and Dardanus Paul'son from the PANGLAO 2004 Expedition, with description of a new species and a checklist of the hermit crabs of the Philippines (Crustacea: Anomura: Paguroidea). Raffles Bulletin of Zoology, 66, 23-65.

Mandai, S.S., Buranelli, R.C. \& Mantelatto, F.L. (2018) Color patterns of the hermit crab Calcinus tibicen (Herbst, 1791) fail to indicate high genetic variation within COI gene. Nauplius, 26, e2018008. 
https://doi.org/10.1590/2358-2936e2018008

Mantelatto, F.L., Pezzuto, P.R., Masello, A., Wongtschowski, C.L.D.B.R., Hilsdorf, A.W.S. \& Rossi, N. (2014) Molecular analysis of the commercial deep-sea crabs Chaceon ramosae and Chaceon notialis (Brachyura, Geryonidae) reveals possible cryptic species in the South Atlantic. Deep Sea Research Part I: Oceanographic Research Papers, 84, $29-37$. https://doi.org/10.1016/j.dsr.2013.10.001

Mathews, L.M., Schubart, C.D., Neigel, J.E. \& Felder, D.L. (2002) Genetic, ecological, and behavioural divergence between two sibling snapping shrimp species (Crustacea: Decapoda: Alpheus). Molecular Ecology, 11 (8), 1427-1437. https://doi.org/10.1046/j.1365-294X.2002.01539.x

McLaughlin, P.A. (1983) Hermit crabs - are they really polyphyletic? Journal of Crustacean Biology, 3 (4), $608-621$. https://doi.org/10.1163/193724083X00274

McLaughlin, P.A. (2002) Pseudopaguristes, a new and aberrant genus of hermit crabs (Anomura: Paguridea: Diogenidae). Micronesica, 34 (2), 185-199.

McLaughlin, P. \& Provenzano, A.J. (1974) Hermit crabs of the genus Paguristes (Crustacea: Decapoda: Diogenidae) from the Western Atlantic part I: the Paguristes tortugae complex, with notes on variation. Bulletin of Marine Science, 24 (1), 165-234.

McLaughlin, PA. \& Provenzano, A.J. (1975) The genus Paguristes (Crustacea: Decapoda: Diogenidae) from the western Atlantic. Part II. Six new species. Bulletin of Marine Science, 24 (4), 885-938.

McLaughlin, P.A. \& Lemaitre, R. (1997) Carcinization in the Anomura-fact or fiction? I. Evidence from adult morphology. Bijdragen tot de Dierkunde, 67 (2), 79-124. https://doi.org/10.1163/18759866-06702001

McLaughlin, P.A. \& Rahayu, D.L. (2005) Two new species of Paguristes sensu stricto (Decapoda: Anomura: Paguroidea: Diogenidae) and a review of Paguristes pusillus Henderson. Zootaxa, 1083 (1), 37-62. https://doi.org/10.11646/zootaxa.1083.1.2

McLaughlin, P.A., Lemaitre, R. \& Sorhannus, U. (2007) Hermit crab phylogeny: a reappraisal and its "fall-out". Journal of Crustacean Biology, 27 (1), 97-115. https://doi.org/10.1651/S-2675.1

McLaughlin, P.A., Komai, T., Lemaitre, R. \& Rahayu, D.L. (2010) Annotated checklist of anomuran decapod crustaceans of the world (exclusive of the Kiwaoidea and families Chirostylidae and Galatheidae of the Galatheoidea). Part I. Lithodoidea, Lomisoidea and Paguroidea. Raffles Bulletin of Zoology, Supplement 23, 5-107.

Mendoza, J.C.E. (2013) A new species of ocellated Xanthias Rathbun, 1897 (Crustacea: Decapoda: Brachyura: Xanthidae) from the Bohol Sea, Philippines. Zootaxa, 3636 (2), 374-384. https://doi.org/10.11646/zootaxa.3636.2.8

Miller, M.A., Pfeiffer, W. \& Schwartz, T. (2010) Creating the CIPRES Science Gateway for inference of large phylogenetic trees. In: Proceedings of the Gateway Computing Environments Workshop (GCE), New Orleans, Louisiana, USA, 14 November 2010, pp. 1-8. https://doi.org/10.1109/GCE.2010.5676129

Miyake, S. (1978) The Crustacea Anomura of Sagami Bay. Biological Laboratory, Imperial Household, Tokyo, 200 pp. [English]

Morrison, C.L., Harvey, A.W., Lavery, S., Tieu, K., Huang, Y. \& Cunningham, C.W. (2002) Mitochondrial gene rearrangements confirm the parallel evolution of the crab-like form. Proceedings of the Royal Society of London B: Biological Sciences, 269 (1489), 345-350. https://doi.org/10.1098/rspb.2001.1886

Mort, M.E., Soltis, P.S., Soltis, D.E. \& Mabry, M.L. (2000) Comparison of three methods for estimating internal support on phylogenetic trees. Systematic Biology, 49 (1), 160-171. https://doi.org/10.1080/10635150050207456

Negri, M., Pileggi, L.G. \& Mantelatto, F.L. (2012) Molecular barcode and morphological analyses reveal the taxonomic and biogeographical status of the striped-legged hermit crab species Clibanarius sclopetarius (Herbst, 1796) and Clibanarius vittatus (Bosc, 1802) (Decapoda: Diogenidae). Invertebrate Systematics, 26 (6), 561-571. https://doi.org/10.1071/IS12020

Negri, M., Lemaitre, R. \& Mantelatto, F.L. (2014) Molecular and morphological resurrection of Clibanarius symmetricus, a cryptic species hiding under the name for the "Thinstripe" Hermit Crab C. vittatus (Decapoda: Anomura: Diogenidae). Journal of Crustacean Biology, 34 (6), 848-861. https://doi.org/10.1163/1937240X-00002277

Ng, P.K. \& Huang, J.F. (1997) Unrecorded crabs (Crustacea: Decapoda: Brachyura) from Taiwan and Tungsha Islands, with description of a new genus and species of Xanthidae. Zoological Studies of Taipei, 36, 261-276.

Nguyen, L., Schmidt, H.A., von Haeseler, A. \& Minh, B.Q. (2015) IQ-TREE: A fast and effective stochastic algorithm for estimating Maximum-Likelihood phylogenies. Molecular Biology and Evolution, 32 (1), 268-274. https://doi.org/10.1093/molbev/msu300

Noever, C. \& Glenner, H. (2018) The origin of king crabs: hermit crab ancestry under the magnifying glass. Zoological Journal of the Linnean Society, 182 (2), 300-318. https://doi.org/10.1093/zoolinnean/zlx033 
Palero, F., Rodríguez-Flores, P.C., Cabezas, P., Machordom, A., Macpherson, E. \& Corbari, L. (2019) Evolution of squat lobsters (Crustacea, Galatheoidea): mitogenomic data suggest an early divergent Porcellanidae. Hydrobiologia, 833 (1), $173-184$. https://doi.org/10.1007/s10750-019-3898-7

Pante, E., Schoelinck, C. \& Puillandre, N. (2015) From integrative taxonomy to species description: one step beyond. Systematic Biology, 64 (1), 152-160. https://doi.org/10.1093/sysbio/syu083

Patoka, J., Blaha, M. \& Kouba, A. (2015) Cherax (Astaconephrops) gherardii, a new crayfish (Decapoda: Parastacidae) from West Papua, Indonesia. Zootaxa, 3964 (5), 526-536. https://doi.org/10.11646/zootaxa.3964.5.2

Pérez-Barros, P., Confalonieri, V.A., Paschke, K. \& Lovrich, G.A. (2015) Incongruence between molecular and morphological characters in the southern king crabs Lithodes santolla and Lithodes confundens (Decapoda: Anomura). Polar Biology, 38 (12), 2097-2107. https://doi.org/10.1007/s00300-015-1770-4

Plaisance, L., Knowlton, N., Paulay, G. \& Meyer, C. (2009) Reef-associated crustacean fauna: biodiversity estimates using semi-quantitative sampling and DNA barcoding. Coral Reefs, 28 (4), 977-986. https://doi.org/10.1007/s00338-009-0543-3

Poupin, J. \& McLaughlin, P.A. (1998) Additional records of Calcinus species (Decapoda: Anomura: Diogenidae) from French Polynesia with description of three new species and a key to Indo-West Pacific species of the genus. Crustacean Research, 27, 9-27. https://doi.org/10.18353/crustacea.27.0_9

Provenzano, A.J. (1959) The shallow-water hermit crabs of Florida. Bulletin of Marine Science, 9, 349-420.

Provenzano, A.J. (1965) Two new West Indian hermit crabs of the genus Paguristes (Crustacea: Diogenidae). Bulletin of Marine Science, 15 (3), 726-736.

Provenzano, A. \& Rice, A. (1966) Juvenile morphology and the development of taxonomic characters in Paguristes sericeus A. Milne-Edwards (Decapoda, Diogenidae). Crustaceana, 10 (1), 53-69. https://doi.org/10.1163/156854066X00072

Puillandre, N., Macpherson, E., Lambourdière, J., Cruaud, C., Boisselier-Dubayle, M.C. \& Samadi, S. (2011) Barcoding type specimens helps to identify synonyms and an unnamed new species in Eumunida Smith, 1883 (Decapoda: Eumunididae). Invertebrate Systematics, 25, 322-333. https://doi.org/10.1071/IS11022

Rahayu, D.L. (2005) Additions to the Indonesian fauna of the hermit crab genus Pseudopaguristes McLaughlin and a further division of the genus Paguristes Dana (Crustacea: Decapoda: Paguroidea: Diogenidae). Zootaxa, 831 (1), 1-42. https://doi.org/10.11646/zootaxa.831.1.1

Rahayu, D.L. (2006) The genus Paguristes (Crustacea, Decapoda, Diogenidae) from Indonesia, In: Richer de Forges, B. \& Justine, J.L. (Eds.), Tropical Deep-Sea Benthos, Vol. 24. Memoires du Museum National d'Histoire Naturelle, Paris, 193, 349-374.

Rahayu, D.L. (2008) The genus Pseudopaguristes McLaughlin (Crustacea: Decapoda: Anomura: Diogenidae) from the southwestern Pacific, with the descriptions of two new species. Zootaxa, 1840 (1), 54-66. https://doi.org/10.11646/zootaxa.1840.1.2

Rahayu, D.L. \& McLaughlin, P.A. (2006) Clarifications of the identities of Paguristes balanophilus Alcock, 1905 and P. calvus Alcock, 1905 (Crustacea, Decapoda, Anomura, Paguroidea, Diogenidae), and the description of another broadly distributed new species. Zoosystema, 28 (4), 865-886.

Rahayu, D.L. \& Mclaughlin, P.A. (2010) Areopaguristes, a generic replacement name for Stratiotes Thomson, 1899 (Crustacea: Decapoda: Paguroidea: Diogenidae). Zootaxa, 2509 (1), 67-68. https://doi.org/10.11646/zootaxa.2509.1.6

Regier, J.C., Mitter, C., Zwick, A., Bazinet, A.L., Cummings, M.P., Kawahara, A.Y., Sohn, J.C., Zwickl, D.J., Cho, S., Davis, D.R. \& Baixeras, J. (2013) A large-scale, higher-level, molecular phylogenetic study of the insect order Lepidoptera (moths and butterflies). PLoS One, 8 (3), e58568. https://doi.org/10.1371/journal.pone.0058568

Reimann, A., Richter, S. \& Scholtz, G. (2011) Phylogeny of the Anomala (Crustacea, Decapoda, Reptantia) based on the ossicles of the foregut. Zoologischer Anzeiger, 250 (4), 316-342. https://doi.org/10.1016/j.jcz.2011.05.006

Rhyne, A.L. \& Lin, J. (2006) A western Atlantic peppermint shrimp complex: Redescription of Lysmata wurdemanni, description of four new species, and remarks on Lysmata rathbunae (Crustacea: Decapoda: Hippolytidae). Bulletin of Marine Science, 79 (1), 165-204.

Rodríguez, F.J., Oliver, J.L., Marín, A. \& Medina, J.R. (1990) The general stochastic model of nucleotide substitution. Journal of Theoretical Biology, 142 (4), 485-501. https://doi.org/10.1016/s0022-5193(05)80104-3

Sanderson, M.J. (1995) Objections to bootstrapping phylogenies: a critique. Systematic Biology, 44 (3), $299-320$. https://doi.org/10.2307/2413594

Schmitt, W.L. (1933) Four new species of decapod crustaceans from Porto Rico. American Museum Novitiates, 662, 1-9. 
Schnabel, K.E., Ahyong, S.T. \& Maas, E.W. (2011) Galatheoidea are not monophyletic-Molecular and morphological phylogeny of the squat lobsters (Decapoda: Anomura) with recognition of a new superfamily. Molecular Phylogenetics and Evolution, 58 (2), 157-168. https://doi.org/10.1016/j.ympev.2010.11.011

Scholtz, G. \& Richter, S. (1995) Phylogenetic systematics of the reptantian Decapoda (Crustacea: Malacostraca). Zoological Journal of the Linnean Society, 113 (3), 289-328. https://doi.org/10.1111/j.1096-3642.1995.tb00936.x

Schweitzer, C.E. \& Feldman, R.M. (2001) New Cretaceous and Tertiary crustaceans from western North America. Bulletin of the Mizunami Fossil Museum, 28, 173-210.

Shimodaira, H. (2002) An approximately unbiased test of phylogenetic tree selection. Systematic Biology, 51 (3), $492-508$. https://doi.org/10.1080/10635150290069913

Shimodaira, H. \& Hasegawa, M. (1999) Multiple comparisons of log-likelihoods with applications to phylogenetic inference. Molecular Biology and Evolution, 16 (8), 1114-1116. https://doi.org/10.1093/oxfordjournals.molbev.a026201

Soledade, G.O., Terossi, M., Scioli, J.A., Mantelatto, F.L. \& Almeida, A.O. (2019) A new western Atlantic snapping shrimp of the Alpheus macrocheles group (Caridea, Alpheidae) revealed by morphological, molecular and color data. European Journal of Taxonomy, 581, 1-21. https://doi.org/10.5852/ejt.2019.581

Soltis, P.S. \& Soltis, D.E. (2003) Applying the bootstrap in phylogeny reconstruction. Statistical Science, 18 (2) $256-267$. https://doi.org/10.1214/ss/1063994980

Susko, E. (2010) First-order correct bootstrap support adjustments for splits that allow hypothesis testing when using maximum likelihood estimation. Molecular Biology and Evolution, 27 (7), 1621-1629. https://doi.org/10.1093/molbev/msq048

Stamatakis, A. (2006) RAxML-VI-HPC: maximum likelihood-based phylogenetic analyses with thousands of taxa and mixed models. Bioinformatics, 22 (21), 2688-2690. https://doi.org/10.1093/bioinformatics/btl446

Strasser, K.M. \& Price, W.W. (1999) An annotated checklist and key to hermit crabs of Tampa Bay, Florida, and surrounding waters. Gulf and Caribbean Research, 11 (1), 33-50. https://doi.org/10.18785/grr.1101.06

Tan, M.H., Gan, H.M., Lee, Y.P., Linton, S., Grandjean, F., Bartholomei-Santos, M.L., Miller, A.D. \& Austin, C.M. (2018) ORDER within the chaos: Insights into phylogenetic relationships within the Anomura (Crustacea: Decapoda) from mitochondrial sequences and gene order rearrangements. Molecular Phylogenetics and Evolution, 127, 320-331. https://doi.org/10.1016/j.ympev.2018.05.015

Tourinho, J.L., Solé-Cava, A.M. \& Lazoski, C. (2012) Cryptic species within the commercially most important lobster in the tropical Atlantic, the spiny lobster Panulirus argus. Marine Biology, 159 (9), 1897-1906. https://doi.org/10.1007/s00227-012-1977-7

Tsang, L.M., Ma, K.Y., Ahyong, S.T., Chan, T.Y. \& Chu, K.H. (2008) Phylogeny of Decapoda using two nuclear protein coding genes: Origin and evolution of the Reptantia. Molecular Phylogenetics and Evolution, 48 (1), 359-368. https://doi.org/10.1016/j.ympev.2008.04.009

Tsang, L.M., Chan, T.Y., Ahyong, S.T. \& Chu, K.H. (2011) Hermit to king, or hermit to all: multiple transitions to crab-like forms from hermit crab ancestors. Systematic Biology, 60 (5), 616-629. https://doi.org/10.1093/sysbio/syr063

Tudge, C. (1997) Phylogeny of the Anomura (Decapoda, Crustacea): Spermatozoa and spermatophore morphological evidence. Contributions to Zoology, 67 (2), 125-141. https://doi.org/10.1163/18759866-06702002

Vaidya, G., Lohman, D.J. \& Meier, R. (2011) SequenceMatrix: concatenation software for the fast assembly of multi-gene datasets with character set and codon information. Cladistics, 27 (2), 171-180. https://doi.org/10.1111/j.1096-0031.2010.00329.x

Vrijenhoek, R.C. (2009) Cryptic species, phenotypic plasticity, and complex life histories: assessing deep-sea faunal diversity with molecular markers. Deep Sea Research Part II: Topical Studies in Oceanography, 56 (19-20), 1713-1723. https://doi.org/10.1016/j.dsr2.2009.05.016

Wass, M.L. (1955) The decapod crustaceans of Alligator Harbor and adjacent inshore areas of northwestern Florida. Quarterly Journal of the Florida Academy of Sciences, 18 (3), 129-176.

Wass, M.L. (1963) New species of hermit crabs (Decapoda, Paguridae) from the western Atlantic. Crustaceana, 6 (2), $133-$ 157. https://doi.org/10.1163/156854063X00525

Wiens, J.J. (2003) Incomplete taxa, incomplete characters, and phylogenetic accuracy: is there a missing data problem? Journal of Vertebrate Paleontology, 23 (2), 297-310. https://doi.org/10.1671/0272-4634(2003)023[0297:ITICAP]2.0.CO;2

Williams, A.B. (1965) Marine decapod crustaceans of the Carolinas. Fishery Bulletin of the Fish and Wildlife Service, 65 (1), $1-298$. 
Williams, A.B. \& Felder, D.L. (1986) Analysis of stone crabs: Menippe mercenaria (Say), restricted, and a previously unrecognized species described (Decapoda: Xanthidae). Proceedings of the Biological Society of Washington, 99 (3), $517-543$.

Wolfe, J.M., Breinholt, J.W., Crandall, K.A., Lemmon, A.R., Lemmon, E.M., Timm, L.E., Siddall, M.E. \& Bracken-Grissom, H.D. (2019) A phylogenomic framework, evolutionary timeline and genomic resources for comparative studies of decapod crustaceans. Proceedings of the Royal Society B, 286 (1901), 20190079. https://doi.org/10.1098/rspb.2019.0079

WoRMS Editorial Board (2020) World Register of Marine Species. VLIZ. Available from: http://www.marinespecies.org (accessed 14 August 2020) https://doi.org/10.14284/170

Zwickl, D.J. \& Hillis, D.M. (2002) Increased taxon sampling greatly reduces phylogenetic error. Systematic Biology, 51 (4), 588-598.

https://doi.org/10.1080/10635150290102339 